\title{
OHVT
}

\section{TECHNOLOGY ROADMAP}

Office of Heavy Vehicle Technologies (OHVT) Office of Transportation Technology

\section{October 1997}
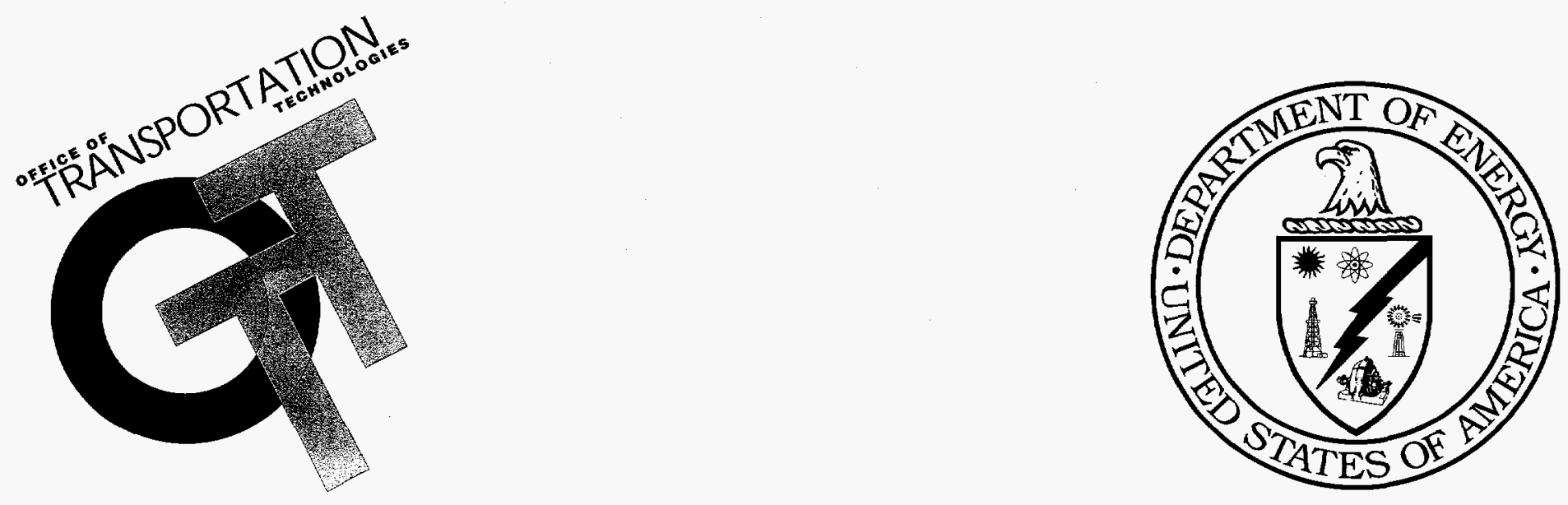


\section{DISCLAIMER}

"This report was prepared as an account of work sponsored by an agency of the United States Government. Neither the United States Government nor any agency thereof, nor any of their employees, makes any warranty, express or implied, or assumes any legal liability or responsibility for the accuracy, completeness, or usefulness of any information, apparatus, product, or process disclosed, or represents that its use would not infringe privately owned rights. Reference herein to any specific commercial product, process, or service by trade name, trademark, manufacturer, or otherwise, does not necessarily constitute or imply its endorsement, recommendation, or favoring by the United States Government or any agency thereof. The views and opinions of authors expressed herein do not necessarily state or reflect those of the United States Government or any agency thereof." 


\section{DISCLAIMER}

Portions of this document may be illegible electronic image products. Images are produced from the best available original document. 
Foreward

This Technology Roadmap was prepared for the U.S. Department of Energy (DOE) Office of Heavy Vehicle Technologies (OHVT) as recommended by the heavy vehicle industry participants in an industry/government workshop held in April 1996. The Roadmap has been developed by DOE in conjunction with national laboratories. This was the first step in crafting a common vision for a government and industry R\&D partnership and was reviewed by engine and vehicle industry representatives at the Society of Automotive Engineers (SAE) Truck and Bus Meeting and Exposition in October 1996. This Roadmap serves as the foundation for the OHVT multiyear program plan. 


\section{Acknowledgments}

The authors and contributors to the OHVT Technical Roadmap are acknowledged below. The Department of Energy's Office of Heavy Vehicle Technologies is grateful for their efforts.

Department of Energy: Dr. Sidney Diamond, Stephen J. Goguen, Robert B. Schulz, William L. Siegel, Richard N. Wares

Oak Ridge National Laboratory: Dr. Ron Bradley (overall project leader), Dr. Ron Graves, Dr. Ray Johnson, Dr. Arvid Pasto, and particularly Pam Werzel and Rita Thearp for document preparation.

Argonne National Laboratory: Dr. Jules Routbort, Roy Cuenca, Dr. Henry Ng, Frank Stodolsky

National Renewable Energy Laboratory: Brent Bailey, Rob Motta, Paul Norton, Barbara Goodman

Sandia National Laboratory: Dr. Robert Carling

Energetics: Dr. Rene Abarcar, Christina Gikakis

The review and comments by representatives of the heavy vehicle manufacturers, engine manufacturers, heavy vehicle users, trade associations and other laboratories were of utmost importance and are also recognized. Represented at the October 1996 review meeting for this Roadmap were:

\begin{tabular}{|ll|}
\hline American Trucking Association & Caterpillar, Inc. \\
Mack Trucks, Inc. & Ames Lab \\
FEV Engine Technology & Motor Coach Ind. \\
Navistar & Detroit Diesel Corporation \\
Ford Motor Company & General Motors \\
Cummins Engine Company & Renault V.I. \\
Lucas Varity & Los Alamos National Laboratory \\
Lawrence Livermore National Laboratory & Idaho National Engineering Laboratory \\
United Parcel Service & Brookhaven National Laboratory \\
\hline
\end{tabular}

Dr. James J. Eberhardt

Director, Office of Heavy Vehicle Technologies 
Table of Contents

I. Executive Summary $\ldots \ldots \ldots \ldots \ldots \ldots \ldots \ldots \ldots \ldots \ldots \ldots \ldots \ldots \ldots$

I. Introduction $\ldots \ldots \ldots \ldots \ldots \ldots \ldots \ldots \ldots \ldots \ldots \ldots \ldots \ldots \ldots$

III. Strategic Importancy of the Heavy Vehicle Technology Program $\ldots \ldots \ldots \ldots$

IV. Technical Plan $\ldots \ldots \ldots \ldots \ldots \ldots \ldots \ldots \ldots \ldots \ldots \ldots \ldots \ldots$

A. Class $7 \& 8$ Trucks $\ldots \ldots \ldots \ldots \ldots \ldots \ldots \ldots \ldots \ldots \ldots \ldots \ldots \ldots$

1. Goals . . . . . . . . . . . . . . 13

2. Engine Efficiency for $10 \mathrm{mpg}$ Truck $\ldots \ldots \ldots \ldots \ldots \ldots \ldots$

a. Status of Technology $\ldots \ldots \ldots \ldots \ldots \ldots \ldots \ldots \ldots \ldots$

b. Technical Targets $\ldots \ldots \ldots \ldots \ldots \ldots \ldots \ldots \ldots \ldots \ldots$

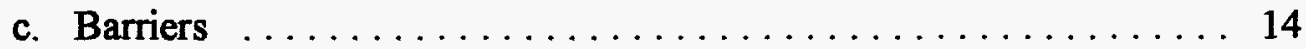

d. Technical Approach $\ldots \ldots \ldots \ldots \ldots \ldots \ldots \ldots \ldots$

3. Power Requirements for 10 mpg Truck $\ldots \ldots \ldots \ldots \ldots \ldots 17$

a. Status of Technology $\ldots \ldots \ldots \ldots \ldots \ldots \ldots \ldots \ldots \ldots$

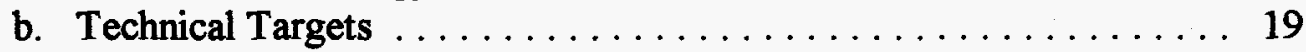

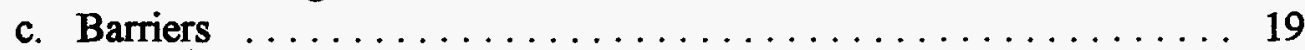

d. Technical Approach $\ldots \ldots \ldots \ldots \ldots \ldots \ldots \ldots \ldots \ldots \ldots$

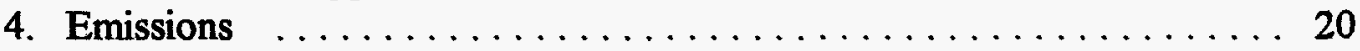

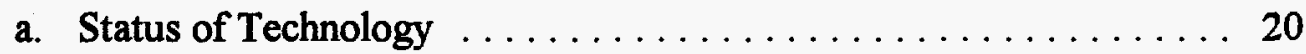

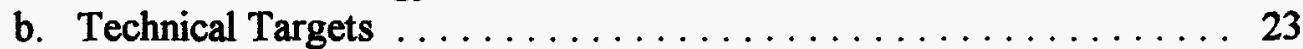

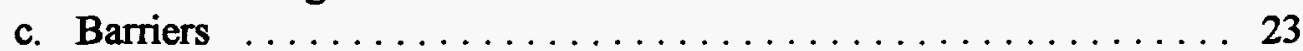

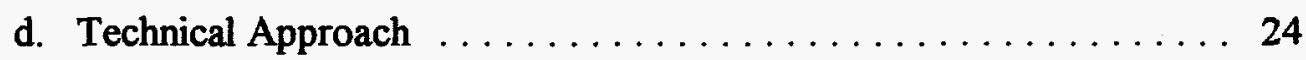

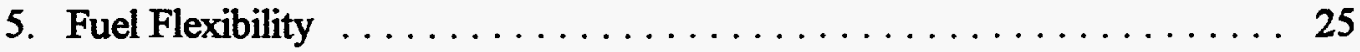

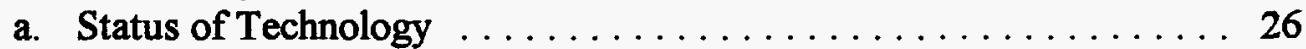

b. Technical Targets $\ldots \ldots \ldots \ldots \ldots \ldots \ldots \ldots \ldots \ldots \ldots$

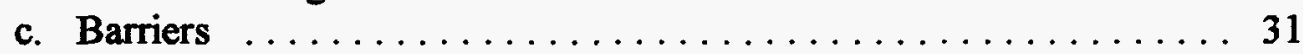

d. Technical Approach $\ldots \ldots \ldots \ldots \ldots \ldots \ldots \ldots \ldots \ldots \ldots$

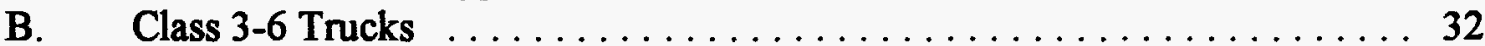

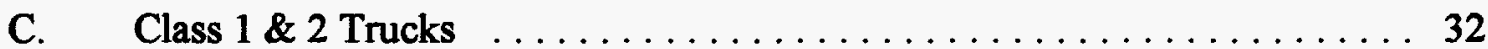

1. Goals ............................. 33

2. $35 \%$ Fuel Efficiency Improvement - $45 \%$ Efficient Diesel Engine . . . . 33

a. Status of Technology $\ldots \ldots \ldots \ldots \ldots \ldots \ldots \ldots \ldots$

b. Technical Targets $\ldots \ldots \ldots \ldots \ldots \ldots \ldots \ldots \ldots \ldots \ldots \ldots$

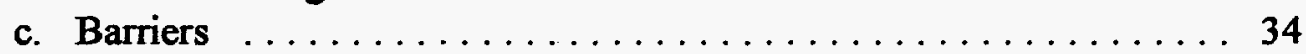

d. Technical Approach $\ldots \ldots \ldots \ldots \ldots \ldots \ldots \ldots \ldots \ldots \ldots \ldots \ldots$

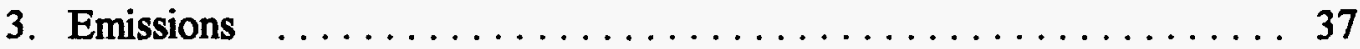

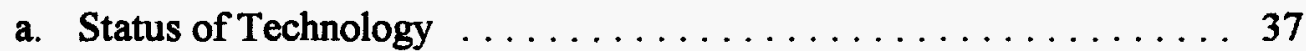

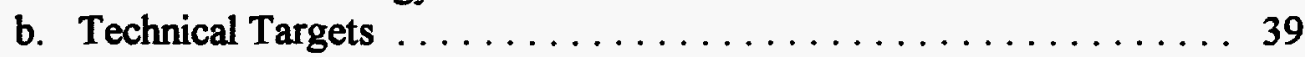

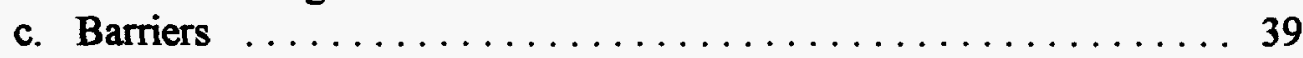

d. Technical Approach $\ldots \ldots \ldots \ldots \ldots \ldots \ldots \ldots \ldots \ldots$ 
IV. Technical Plan (cont'd)

C. Class $1 \& 2$ Trucks

4. NVH, Odor, and Cold Weather Limitations of Diesels. . . . . . . . 40

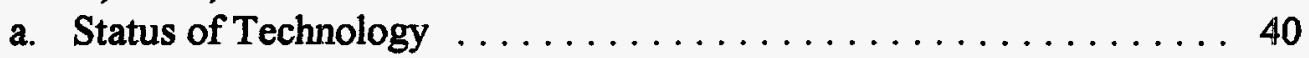

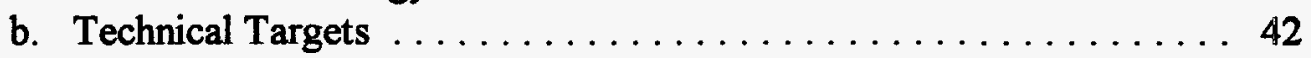

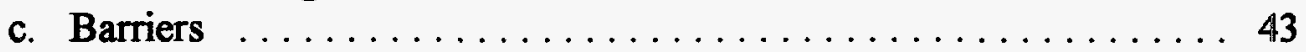

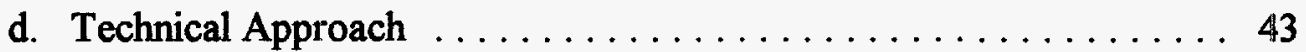

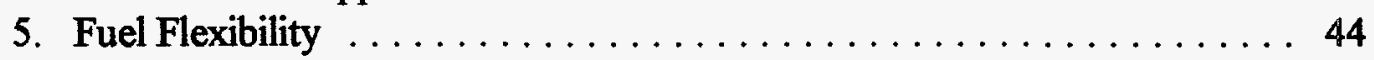

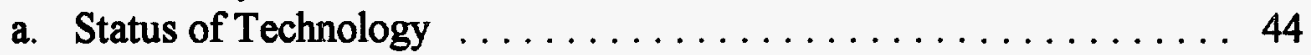

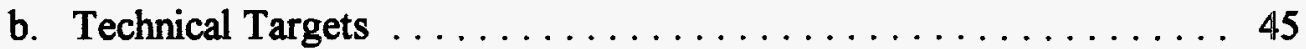

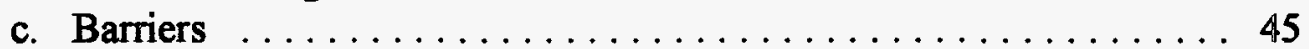

d. Technical Approach $\ldots \ldots \ldots \ldots \ldots \ldots \ldots \ldots \ldots \ldots \ldots \ldots$

v. Program Summary $\ldots \ldots \ldots \ldots \ldots \ldots \ldots \ldots \ldots \ldots \ldots \ldots \ldots \ldots \ldots \ldots \ldots \ldots$

VI. Appendices

A. OHVT Workshops and Meetings $\ldots \ldots \ldots \ldots \ldots \ldots \ldots \ldots \ldots 49$

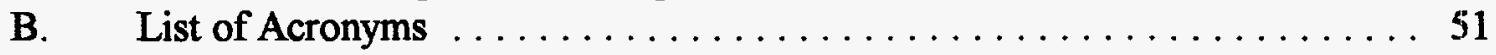

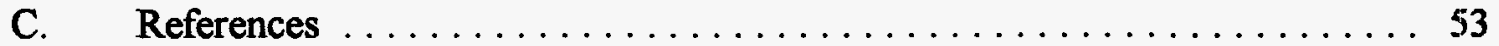




\section{Executive Summary}

The Office of Heavy Vehicle Technologies (OHVT) is one of four component offices within the Office of Transportation Technologies (OTT). OHVT was formed in March 1996 to focus R\&D efforts on the needs of heavy vehicle customers. This Technology Roadmap for the Department of Energy's (DOE) Office of Heavy Vehicle Technologies (OHVT) was developed as a first step in crafting a common vision for a government and industry research and development (R\&D) partnership in this increasingly important transportation sector. Shortly after its formation in March 1996, the OHVT convened a workshop (April 1996) to elicit input from DOE's heavy vehicle industry customers, including truck and bus manufacturers, diesel engine manufacturers, fuel producers, suppliers to these industries, and the trucking industry. The preparation of this Technology Roadmap was one of the key recommendations by the customer group.

OHVT formed a team from DOE and its national laboratories [Oak Ridge National Laboratory (ORNL), National Renewable Energy Laboratory (NREL), Sandia National Laboratory (SNL), and Argonne National Laboratory (ANL)] to develop the roadmap. The approach to the roadmap was to:

- formulate goals consistent with the DOE strategic plan required by the Government Performance and Results Act (GPRA),

- assess the status of the technology,

- identify technical targets,

- identify barriers to achieving the technical targets,

- develop an approach to overcoming the barriers, and

- develop schedules and milestones.

This structure was followed for three groups of truck classification:

- $\quad$ Class 7-8, large on-highway trucks

- Class 3-6, medium duty trucks such as delivery vans

- Class 1-2 trucks, pickups, vans, and sport utility vehicles

The Department of Energy's Office of Heavy Vehicle Technologies (OHVT) envisions the development of a fuel-flexible, energy efficient, near-zero emissions heavy-duty U.S. diesel engine technology devolving into all truck classes as a real and viable strategy for reducing energy requirements for commercial transport services and the rapidly growing multi-purpose vehicle market (pickups, vans, and sport utility vehicles). The first Multiyear Program Plan for the OHVT has recently been drafted.

The foundation of the Office of Heavy Vehicle Technologies Technology Roadmap is the Strategic Plan for the Office of Transportation Technologies (OTT) published in August of 1996 and the DOE Strategic Plan published in September of 1997. The Strategic Plan 
addresses the energy, economic, and environmental challenges in meeting the future demand for transportation goods and services. The strategic vision of the Office of Transportation Technologies which supports the DOE Strategic Plan is that "within the first decade of the twenty-first century, the United States will turn the corner in the growth of petroleum use for highway transportation." In particular, energy use by heavy vehicles (trucks and other commercial transport) is growing at a faster rate than automobiles. Indeed, because of the explosive growth in popularity of pick-up trucks, vans, and short utility vehicles, trucks of all classes already exceed passenger cars in annual fuel consumed.

The OHVT Technology Roadmap was reviewed by industry stakeholders, who provided comments at a second workshop, held October 15, 1996, in conjunction with the Society of Automotive Engineers International Truck and Bus Meeting and Exposition.

The Technical Roadmap documented program goals and identified in the workshops a technical approach for their attainment.

\section{Program Goals}

- Develop by 2002 the diesel engine enabling technologies to support large-scale industry dieselization of Class 1-2 trucks, achieving a 35 percent fuel efficiency ${ }^{*}$ improvement over equivalent gasoline-fueled trucks,

- Develop by 2004 the enabling technology for a Class 7-8 truck with a fuel efficiency of $10 \mathrm{mpg}$ (at $65 \mathrm{mph}$ ) which will meet prevailing emission standards, using either diesel or a liquid alternative fuel,

- Develop by 2006 diesel engines with fuel flexibility and a thermal efficiency of 55 percent with liquid alternative fuels, and a thermal efficiency of 55 percent with dedicated gaseous fuel.

\section{Program Approach}

(1) A partnership with the domestic transportation industry, energy supply industry, other federal agencies, and research and development organizations to develop highefficiency engine technologies and alternative fuel utilization technologies for trucks and promote their acceptance

\footnotetext{
*A 50 percent increase in miles per gallon due to diesel fuel higher energy content per
} gallon. 
(2) Continuing development of key enabling technologies.

- Combustion

- Exhaust Aftertreatment

- Materials

- $\quad$ Fuels formulation

- Natural Gas Storage

- Environmental Effects

Three of these enabling technologies, combustion, exhaust afterteatment, and fuels formulation, are being coordinated through a diesel cross-cut team that has linked diesel R\&D in the OHVT to analogous activities being proposed under the Partnership for a New Generation of Vehicles (PNGV). 



\section{Introduction}

The transportation sector is the single largest user of petroleum in the United States. The energy required by heavy vehicles, especially truck highway energy use, is growing - and at a faster rate than that of automobiles. Trucks of all classes use more energy than automobiles (see Figure 1). ${ }^{(1,2)}$

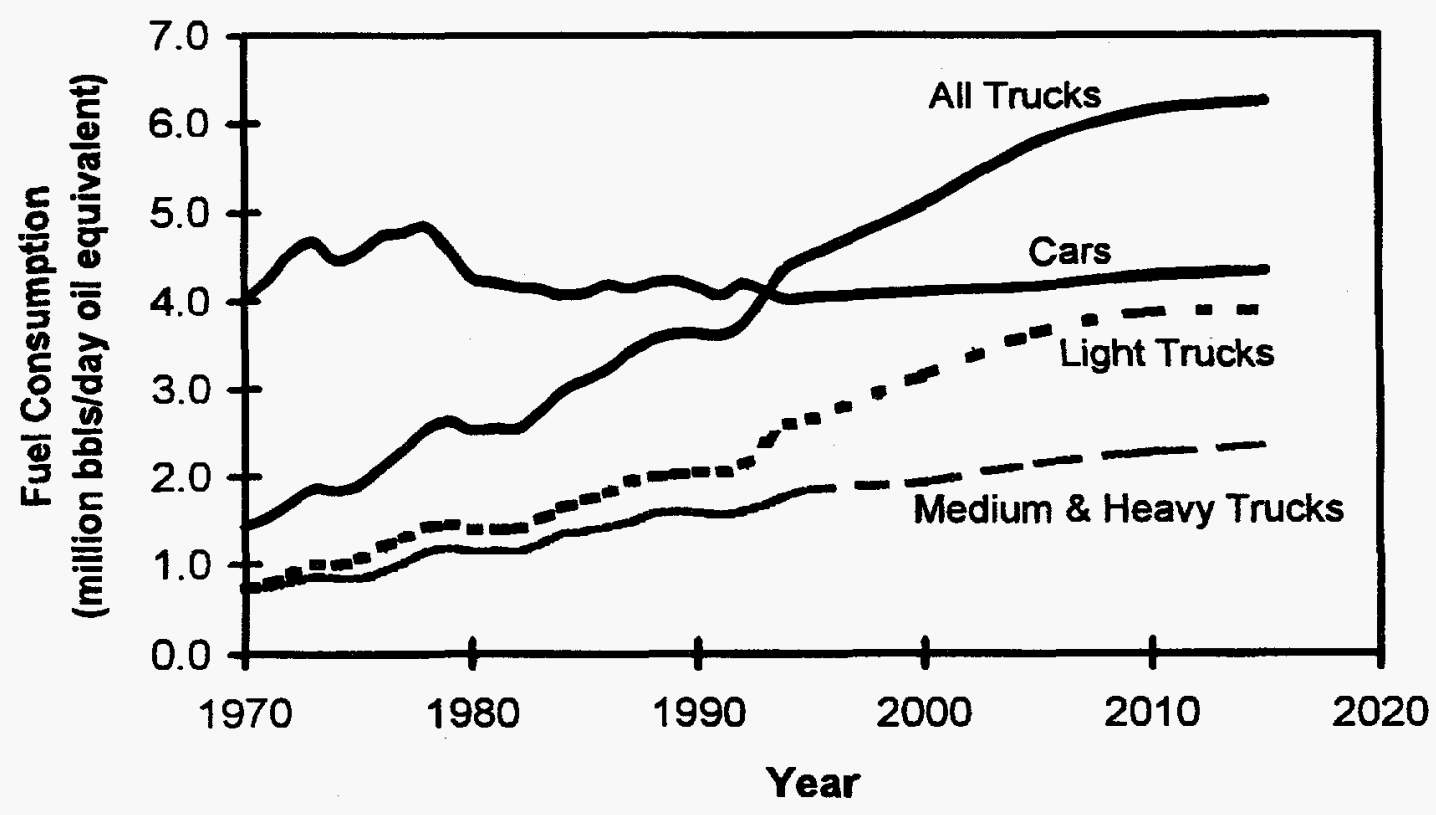

Figure 1. Trucks Account for an Increasing Amount of Highway Transportation Energy Use.

"The United States faces major challenges in meeting the ever-growing demand for transportation goods and services while minimizing adverse energy, environmental, and economic impacts. The total transportation sector of the U.S. remains over 97 percent dependent on petroleum fuels and 
consumes approximately two-thirds of the nation's oil demand. Highway transportation alone uses over half of the nation's oil demand, while the number of vehicles on our roads and miles driven continue to steadily increase. As a result, U.S. oil import demands continue to rise concurrently with an increase in the global demand for oil. Meanwhile, worldwide oil reserves are becoming more concentrated in a snaller number of countries, many of which are often politically unstable and opposed to U.S. interests.

This situation leaves us increasingly vulnerable to the potentially serious adverse economic impacts of disnuptions in oil supply. The large and growing levels of oil imports also represent a major transfer of wealth from the United States to oil exporting countries; in 1995, this was about of $\$ 49$ billion.

There is also continuing concern on the part of many U.S. citizens about the poor air quality in our cities and increasing levels of greenhouse gases. Fiftyfour million Americans live in counties (mostly urban) that regularly do not meet air quality standards. Polluting emissions from transportation sources remain a major contributor to this problem .

Another national concern is the global market competition in the transportation sector. There is a critical need for the United States to further develop and nurture an advanced transportation technologies base that will enable domestic producers to meet the strong competitive threat from imports and take advantage of the opportunities offered by the rapidly growing overseas market for motor vehicles.

In order to effectively address the above challenges, it is essential that all of our available resources be integrated and focused on a common vision, a supporting mission, and time related, clearly defined program goals. Our vision means that the use of petroleum for transportation, which has maintained a generally upward trend for the last several decades, would start decreasing during the first decade of the next century, as a result of the development of advanced transportation technologies and increased use of alternative fuels. Our realization of this vision, through the effective use of domestic resources and products, will immediately reduce our nation's major concerns relative to the transportation sector." (1)

Within DOE-OTT, the Office of Heavy Vehicle Technologies (OHVT) conducts in collaboration with its heavy vehicle industry partners and their suppliers, a customer-focused national program for research and development on critical technologies that will enable the U.S. heavy vehicle transport industry to fully exploit the energy efficiency and alternative fuels capability of the diesel engine while simultaneously reducing highway vehicle emissions. The OHVT heavy vehicle industry customers include truck and bus manufacturers, diesel engine manufacturers, fuel producers, suppliers to these industries, and the trucking industry and 
other truck users (who must purchase and use advanced heavy vehicles before energy savings can be realized). The Heavy Vehicle Technologies Program is collaborating with its industry customers in crafting a common industry/government vision of a Heavy Vehicle Industry of the Future.

The goal of the Heavy Vehicle Technologies Program is to develop by 2004 the enabling technologies needed to achieve a fuel-flexible, ultra-low emissions, 10 mile-per-gallon Class $7 \& 8$ truck and to devolve these technologies down through mid-range trucks (Class 3 to 6) to Class 1 \& 2 trucks, achieving at least 35 percent fuel economy improvement over current gasoline-fueled Class 1-6 trucks.

The Technology Roadmap for a Heavy Vehicle Industry of the Future describes an industry/government $R \& D$ partnership in heavy vehicle technologies in areas of common interest and where expertise could be shared to achieve the vision for a heavy vehicle industry of the future. 



\section{Strategic Importance of the Heavy Vehicle Technology Program}

The Strategic Plan ${ }^{(1)}$ of the DOE Office of Transportation Technologies (OTT) addresses the energy, economic, and environmental challenges in meeting the future demand for transportation goods and services. As stated in the Strategic Plan, OTT's Vision is as follows:

Within the first decade of the twenty-first century, the United States will turn the corner in the growth of petroleum use for highway transportation.

The Heavy Vehicle Technologies Program is an important component of OTT's strategy for achieving its vision since virtually all of the growth in petroleum highway use is due to heavy vehicles. Heavy vehicles represent a target of opportunity of about 10.8 quads of highway transportation use by the year 2010 considering all trucks and buses (12.5 quads if rail, marine, and off-highway uses are included), assuming that there are no changes in the current trend in transportation energy use (see Table 1). Increase in truck energy use is due to the growth in demand for transport of goods and products (provided by Class 3 to 8 trucks) as well as the growth in demand for multi-purpose vehicles (Class $1 \& 2$ trucks which include pickups, vans, and sport utility vehicles). Sales of multi-purpose vehicles (which predominantly use less efficient gasoline engines) have increased dramatically in the past 12 years, from approximately 3 million vehicles in 1983 to 6 million in 1995 (from 25 percent to 42 percent of the foreign and domestic sales in the U.S.).

Table 1. Targets of Opportunity

\begin{tabular}{|l|c|l|l|l|}
\hline & \multicolumn{4}{|c|}{ Oil-derived Energy (Quads) } \\
\hline Vehicle Categories & 1995 & 2000 & 2010 & 2015 \\
\hline \hline Automobiles & 9.5 & 9.6 & 10.0 & 10.0 \\
\hline & & & & \\
\hline Heavy Vehicles (Trucks and others) & 9.7 & 10.7 & 12.5 & 13.0 \\
\hline Class 1-2 Trucks (GVW $<10,000 \mathrm{lbs})$ & 3.7 & 4.3 & 5.1 & 5.2 \\
\hline Class 3-6 Trucks (10,000 lbs $<$ GVW $<26,000 \mathrm{lbs})$ & 1.6 & 1.7 & 2.0 & 2.1 \\
\hline Class 7-8 Trucks ( GVW $>26,000 \mathrm{lbs)}$ & 2.8 & 3.1 & 3.5 & 3.8 \\
\hline Buses & 0.2 & 0.2 & 0.2 & 0.2 \\
\hline Rail & 0.4 & 0.4 & 0.5 & 0.5 \\
\hline Marine & 0.3 & 0.3 & 0.4 & 0.4 \\
\hline Off-highway & 0.7 & 0.7 & 0.8 & 0.8 \\
\hline
\end{tabular}


The health and continued growth of the U.S. economy depends on maintaining the energy security and profitability of the trucking industry, now and into the foreseeable future. Trucks are the mainstay for trade/commerce and economic growth. The gross domestic product (GDP), and hence, economic activity is directly related to freight transport (see Figure 2). Meeting energy demand for movement of goods is, therefore, critical to the economy. In addition, the U.S. truck manufacturing industry represents over $\$ 300$ billion (or approximately 5 percent) of the nation's \$6 trillion GDP. In 1994 trucks accounted for almost $\$ 70$ billion of the total $\$ 246$ billion motor vehicle industry shipments. The heavy vehicle industry (which includes the trucking industry and other truck users, truck manufacturers, engine manufacturers, fuel producers, and component suppliers) as a whole will need to maintain a dominant role in assuring that the U.S. economy remains healthy.

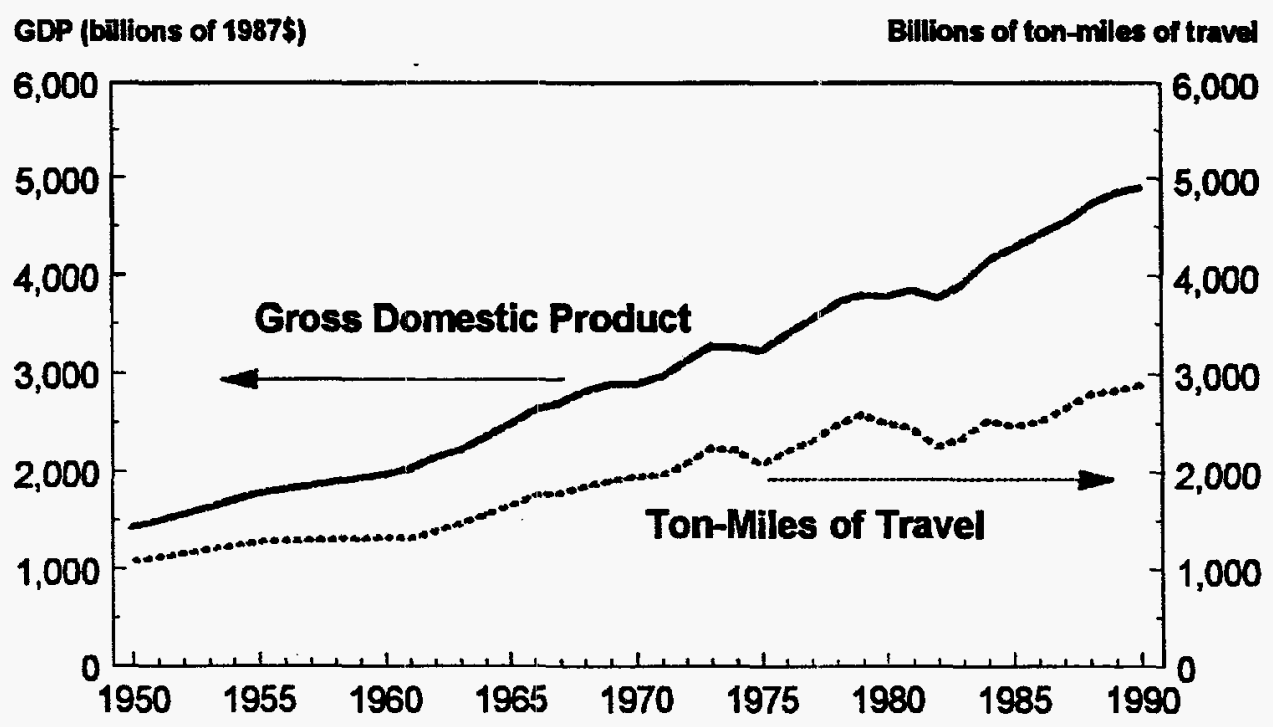

Figure 2. The Nation's Economy is Linked to Efficient

Heavy Vehicle Transportation

The Office of Heavy Vehicle Technologies (OHVT) envisions the development of a fuel-flexible, energy efficient, near-zero emissions heavy-duty U.S. diesel engine technology devolving into all truck classes as a real and viable strategy for reducing energy requirements of commercial transport services and the rapidly growing multi-purpose vehicle market (pickups, vans, and sport utility vehicles). The strategy is two-pronged: a) to improve the efficiency of Class $7 \& 8$ truck diesel engines to 55 percent or more and improve the capability to utilize alternative fuels, while simultaneously reducing emissions to ultra-low or 
near-zero levels; and b) to utilize the expertise of the world class U.S. diesel engine manufacturers in developing highly efficient, ultra- to near-zero emissions diesel engines that will be commercially competitive with gasoline engines in the multi-purpose Class $1 \& 2$ truck markets, achieving at least a 35 percent fuel economy improvement over gasoline-fueled vehicles.

Market penetration of energy efficient technologies will depend on the truck uses. Commercial truck operators will pay a reasonable price for fuel economy improvements of their Class $7 \& 8$ trucks to improve profitability, whereas fuel economy is less important to buyers of multi-purpose Class $1 \& 2$ trucks (especially those predominantly used for personal transportation).

Emissions control technologies are the key enablers for greater utilization of the inherently higher efficiency diesel engines if future heavy vehicles are to meet increasingly more stringent Environmental Protection Agency (EPA) standards. This is the critical requirement for market entry of more energy efficient heavy vehicles before potential energy savings can be realized. Although progress has been made in reducing heavy-duty diesel emissions in the last 20 years the predominantly diesel-powered heavy duty transport sector is a major contributor to criteria pollutant emissions (see Figure 3). Critical technological breakthroughs are necessary to cost-effectively meet EPA standards proposed for the year 2004 and beyond.

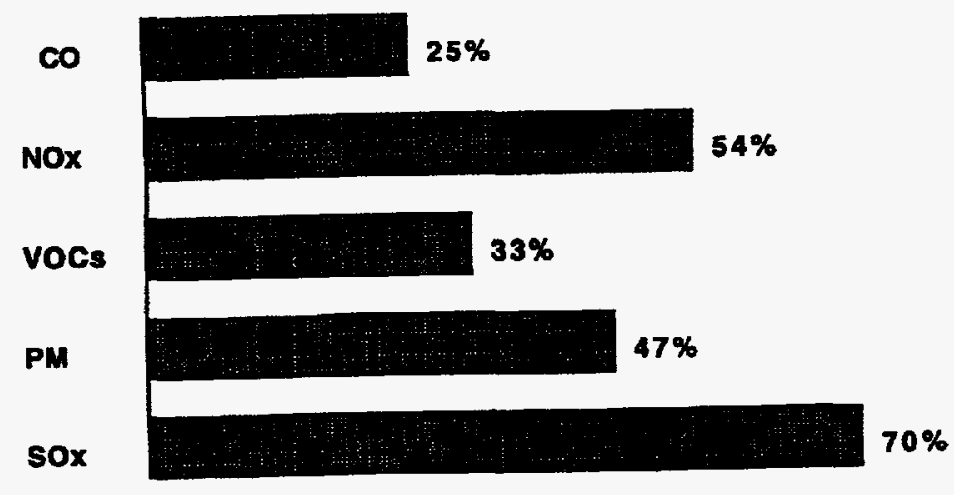

Sonrce: DOE Transportation Energy Data Book: Ealition 14

Figure 3. Contribution to Air Pollution by Heavy Duty Transportation 
. 


\section{Technical Plan}

A. CLASS $7 \& 8$ TRUCKS - The following sections describe the goals for Class $7 \& 8$ trucks, the status of technology for these trucks, the technical targets to be achieved in order to meet these goals, the technical barriers which must be overcome to achieve the technical targets, and the technical approach to overcoming those barriers.

1. Goals

The Program goal with respect to Class $7 \& 8$ trucks is to develop by 2004 the enabling technology for a truck with a fuel efficiency of $10 \mathrm{mpg}$ (at $65 \mathrm{mph}$ ) which will meet prevailing emission standards, using either diesel fuel use or a liquid alternative fuel. A separate task will focus on developing a highly efficient gaseous fuel engine.

The program will achieve this goal by performing research and development required to achieve higher engine efficiency, reduced power requirements, emissions reduction and fuel flexibility.

\section{Engine Efficiency for $10 \mathrm{mpg}$ Truck}

\section{a. Status of Technology}

Due to their high efficiency and reliability, diesel engines are the dominant power source for heavy-duty trucks and for city and intercity buses in the United States, and they are the preferred power source for commercial surface transportation worldwide. Compression ignition (diesel) engines are the most efficient energy conversion devices available, with very large units (e.g., land-based and marine engines) exceeding 50 percent thermal efficiency. ${ }^{(3)}$ Turbocharged diesels for highway trucks are now offered that exceed 46 percent efficiency (compared to about 24 percent for production gasoline engines), an improvement of about 40 percent relative to diesel engines of the late $1970 \mathrm{~s}$. The diesel-engine industry believes that this number can be increased to $50-55$ percent. Data from single-cylinder prototype engines indicate that heavy truck engines could be built today that achieve 52 percent thermal efficiency, albeit durability, emissions, and cost targets are not yet assured.

Diesel engines derive their high efficiency from being designed to emulate high-efficiency thermodynamic cycles and to minimize mechanical losses. The base thermal efficiency of diesels comes about from utilizing a relatively high compression/expansion ratio, combusting fuel at a high rate (approximating the ideal Otto cycle more so than the classic Diesel cycle), and combusting fuel with excess air (lean-burn). ${ }^{(4,5)}$ Diesel engines use air-fuel ratio instead of throttling for load control, thus avoiding the part-load pumping losses characteristic of conventional spark ignition engines. Heavy duty diesels utilize turbocharging which increases power density and utilizes exhaust heat to a limited extent. They are designed to operate at 
relatively low speeds, thereby managing mechanical friction losses. Other design features like strategic cooling serve to minimize thermal energy losses. Turbocompounding is a proven technology for exhaust heat recovery, essentially an additional turbocharger shaft coupled to the engine output shaft. Though proven, it is not considered cost effective at today's U.S. fuel prices.

b. Technical Targets

A brake thermal efficiency of 55 percent for the engine has been set as an aggressive but achievable objective. Major diesel engine companies have considered and concurred with this target. For the most part, further advances in efficiency will be achieved with improvemerts in components and operating characteristics of engines similar in overall architecture to those now widely used. A more detailed presentation of the characteristics of modern diesels, and the targets and barriers for advanced technology are shown in Table 2 . In addition to improvement to the reciprocator assembly, an effective exhaust heat recovery system is critical to meeting the 55 percent efficiency target.

The contributions of the component technical targets to the 55 percent goal are depicted in Figure 4.

\section{c. Barriers}

The barriers that must be overcome to achieve the component technical targets for the 55 percent efficient engine are summarized in Table 2.

\section{d. Technical Approach}

- Define one or more advanced engine designs as reference engines with sufficient detail to delineate the areas where technology advancement is required, serving as a guide for enabling technology projects. Conduct, on a continuing basis, analysis and supporting validation tests to assess progress toward goals.

- Develop advanced combustion chamber components for high peak pressures and high brake mean effective pressures, utilizing, as needed, new architectures for components, new materials, thermal barriers, and novel cooling strategies. Perform materials selection to support engine design targets, pre-component tests and characterization of enabling materials, performance and durability tests of new components, and, finally, tests of complete engine systems. Identify needs for improved materials as required. 
- Develop fuel injection and combustion technologies that will provide higher peak cylinder pressure for better efficiency, without causing higher NOx. Support technology development with modeling and simulation as an integral component of the systems design strategy. Develop and integrate sensors, controls, diagnostics and enabling experimental tools. Emissions aftertreatment may be an approach to allow peak cylinder pressure to be raised without increasing NOx. See emissions section.

Table 2. Summary of 55 Percent Efficient Engine Parameters, Technical Targets, and Barriers

\begin{tabular}{|c|c|c|c|}
\hline Engine Parameter & $\begin{array}{l}\text { Current } \\
\text { Practice }\end{array}$ & $\begin{array}{c}\text { Technical Target for } \\
2004\end{array}$ & Barrier \\
\hline $\begin{array}{l}\text { Peak Cylinder } \\
\text { Pressure, psi }\end{array}$ & $2000-2200$ & $2800-3500$ & $\begin{array}{l}\text { Structural integrity, } \\
\text { thermomechanical fatigue, friction } \\
\text { control, piston/ ring lubrication, } \\
\text { NOx emissions. }\end{array}$ \\
\hline $\begin{array}{l}\text { Turbocharger } \\
\text { Efficiency, percent }\end{array}$ & $50-58$ & $\begin{array}{l}72-76 \text { percent, with } \\
\text { variable geometry or } \\
\text { similar enhancement }\end{array}$ & $\begin{array}{l}\text { Small turbomachinery } \\
\text { aerodynamics, rotor inertia; } \\
\text { materials for low-mass, } \\
\text { aerodynamic rotors. }\end{array}$ \\
\hline $\begin{array}{l}\text { Exhaust heat } \\
\text { recovery }\end{array}$ & $\begin{array}{l}\text { Essentially none } \\
\text { besides } \\
\text { turbocharger }\end{array}$ & $\begin{array}{l}\text { Cost effective, } \\
\text { additional } 12 \text { percent } \\
\text { of exhaust energy } \\
\text { recovered }\end{array}$ & $\begin{array}{l}\text { Cost and complexity of turbo- } \\
\text { compounding; efficiency/cost of } \\
\text { direct conversion; materials for } \\
\text { low-mass, cost-effective rotors; } \\
\text { insulation of exhaust system. }\end{array}$ \\
\hline $\begin{array}{l}\text { Brake mean effective } \\
\text { pressure (bmep), psi }\end{array}$ & $200-240$ & $340-400$ & $\begin{array}{l}\text { Structural integrity and thermo- } \\
\text { mechanical fatigue, see "peak } \\
\text { cylinder pressure" above; } \\
\text { limitations of single-stage } \\
\text { turbochargers; need for adequate } \\
\text { boosting. Fuel injection rate and } \\
\text { quantity. }\end{array}$ \\
\hline $\begin{array}{l}\text { Thermal } \\
\text { management }\end{array}$ & $\begin{array}{l}\text { Water+oil } \\
\text { cooling, radiator }\end{array}$ & $\begin{array}{l}\text { Selective insulation on } \\
\text { piston, ports, head } \\
\text { plate. }\end{array}$ & $\begin{array}{l}\text { Durable cost-effective coatings and } \\
\text { other thermal barriers; TBC } \\
\text { sealing. }\end{array}$ \\
\hline $\begin{array}{l}\text { Engine mechanical } \\
\text { friction }\end{array}$ & & $\begin{array}{l}\text { Provide } 1 \text { percent or } \\
\text { more efficiency } \\
\text { increase. }\end{array}$ & \\
\hline
\end{tabular}


Projected Contributions of Advanced Technologles to Diesel Engine Efficiency Improvement - Total 15\% Increase

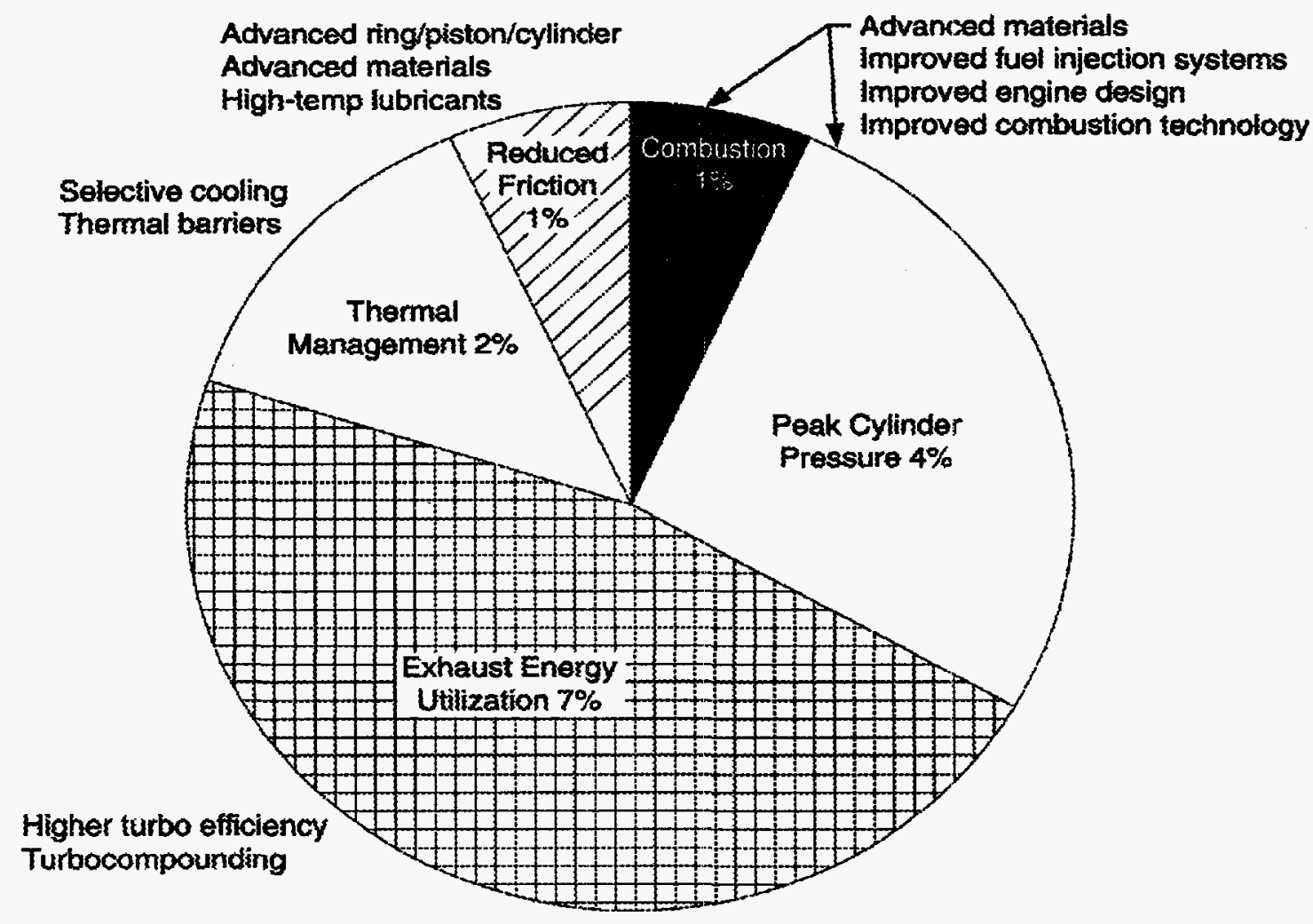

Adapted from: Don Krull, Caterpillar, Inc., Energy Efficient Heavy Vehicles Technologies, "The Engine Manufacturers Perspective," DOE/SAE Workshop on Energy Efficient Heavy Vehicle Technologies for Reducing Fuel Costs:

Leveraging DOE's R\&D Capabilities,"Romulus, Michigan, April 17-18, 1996.

Figure 4 
- Develop improved turbocharger and air-handling systems including: variable geometry technology, improved rotor aerodynamics, and systems controls. Continue systems analysis to reexamine tradeoffs between turbocharger efficiency and transient response and review new low-inertia materials and response-enhancing technologies that may emerge.

- Continue analysis and evaluation of new exhaust heat recovery technologies as they emerge, including direct energy conversion. Fabricate and test heat recovery prototypes that are based on promising new technologies. Develop materials and designs for improved insulation of exhaust systems.

- Continue development of thermal barrier designs and enabling materials. Refine analysis of benefits of cooling and thermal barrier strategies, supported with experiments.

- Continue refinement of piston/cylinder designs, valve-trains, and other mechanical components for reduced friction losses. Carry out research and development of low-friction materials and lubricants.

\section{Power Requirements for 10 mpg Truck}

The realization of $10 \mathrm{mpg}$ trucks will require not only improvements in engine efficiency, but also substantial reductions in the power required to propel the vehicle. This can be achieved by a combination of reduced aerodynamic drag, reduced rolling friction, and reduced parasitic losses. A previous analysis was reviewed and updated to identify the key contributors to truck power requirements. ${ }^{(6,7)}$ A steady highway speed of $65 \mathrm{mph}$ on level roads was taken as the base case, and the present situation for a typical truck is depicted in Figure 5. The steady-state case illustrates the priority power-consumers, although the value of a lower-weight chassis is less apparent than would be in a variable speed driving cycle. The analysis also highlights just how much fuel economy gain can be attributed to engine developments. 


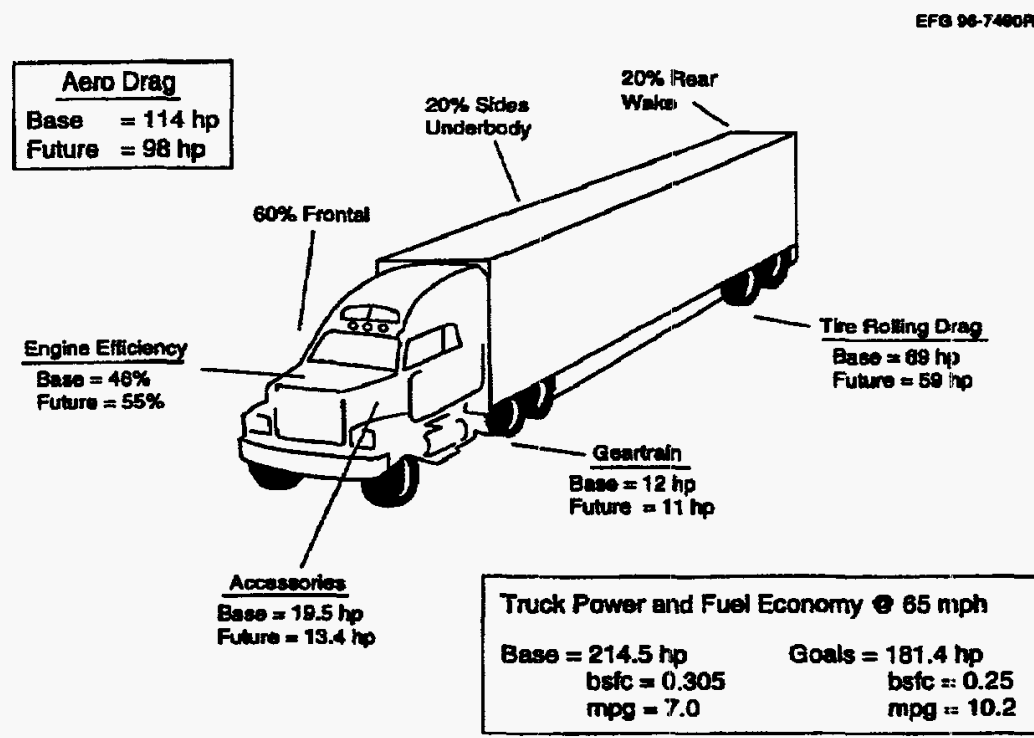

Figure 5

\section{a. Status of Technology}

Truck power requirements are dominated by aerodynamic drag, comprising mainly the form drag, surface drag (skin friction), and internal drag (engine compartment and passenger ventilation). The combination of these gave large highway trucks a drag coefficient $\left(C_{d}\right)$ of near 1.0 for designs of the mid-1970s. Truck cabs with rounded exteriors, plus a combination of air dams, gap seals, and other fairings can reduce the $\mathrm{C}_{\mathrm{d}}$ for the tractor-trailer rig to about 0.55 . Estimates of fuel economy improvements are 14-19 percent for combined aerodynamic treatments to the tractor and trailer. ${ }^{(8)}$

Rolling resistance is the second highest factor in truck power requirements. Already there has been a major shift toward use of radial tires instead of bias ply tires, with a low-profile radial in widespread use. The newest generation tire is the "super single" that offers less rolling drag. It is an available technology offering a few percent fuel savings, but there is user resistance for a variety of reasons. Among the concerns is the lack of redundancy in the event of a failure and perceptions that road damage is higher. The "super singles" are also taller than other radials, thus detracting from the freight volume of a closed van trailer. They are used primarily in the niche application of tanker trucks. 


\section{b. Technical Targets}

The distribution of power requirement comparing a typical Class 8 truck to one with advanced technology is also shown in Figure 5. Clearly the greatest gains are achievable by attacking losses due to aerodynamic and rolling resistance. Mechanical losses in gears, bearings, and auxiliaries become more important as the major power drains are reduced. The technical targets established to achieve reduced truck power requirements for a $10 \mathrm{mpg}$ truck are given in Table 3. ${ }^{(6-1)}$

\section{c. Barriers}

The barriers to achieving the technical targets for reduced truck power requirements are given in Table 3 ( $^{(6-11)}$

Table 3. Summary of 10 mpg Truck Parameters, Technical Targets, and Barriers

\begin{tabular}{|l|l|l|l||}
\hline \multicolumn{1}{|c|}{$\begin{array}{c}\text { Vehicle } \\
\text { Parameter }\end{array}$} & \multicolumn{1}{|c|}{ Current Technology } & \multicolumn{1}{|c|}{ Target } & \multicolumn{1}{c|}{ Barrier } \\
\hline $\begin{array}{l}\text { Aerodynamic } \\
\text { drag }\end{array}$ & $\begin{array}{l}\mathrm{C}_{\mathrm{d}}=0.55 \text { with best available } \\
\text { designs and added farings }\end{array}$ & $\begin{array}{l}\mathrm{C}_{\mathrm{d}}=0.47 \text { (or } 15 \text { percent } \\
\text { reduction in widely used } \\
\text { packages) }\end{array}$ & $\begin{array}{l}\text { Maintenance } \\
\text { nuisance, cost of } \\
\text { aero designs. } \\
\text { Non-optimal } \\
\text { underhood designs, } \\
\text { large radiator. }\end{array}$ \\
\hline $\begin{array}{l}\text { Rolling (tire) } \\
\text { friction losses }\end{array}$ & Low-profile radials & $\begin{array}{l}\text { Reduce rolling resistance by } \\
\mathbf{8} \text { percent (assure use of super } \\
\text { singles) }\end{array}$ & $\begin{array}{l}\text { Road damage and } \\
\text { stability (safety) } \\
\text { concerns for super } \\
\text { single tires; } \\
\text { availability at truck } \\
\text { stops. }\end{array}$ \\
\hline Mechanical losses & $\begin{array}{l}\text { Transmission and axles } \\
\text { account for up to 7 percent of } \\
\text { power requirements }\end{array}$ & Reduce by 25 percent & $\begin{array}{l}\text { Cost-effective } \\
\text { alternative materials } \\
\text { and designs. }\end{array}$ \\
\hline $\begin{array}{l}\text { Auxiliaries, } \\
\text { parasitics }\end{array}$ & $\begin{array}{l}\text { Shaft-driven auxiliaries } \\
\text { account for up to 12 percent } \\
\text { of truck power requirement }\end{array}$ & Reduce by 25 percent & $\begin{array}{l}\text { Cost-effective } \\
\text { alternative materials } \\
\text { and designs. }\end{array}$ \\
\hline
\end{tabular}

References $^{(6-1)}$

\section{d. Technical Approach}

- Update vehicle systems analysis to define fuel savings benefits of specific technical strategies such as aerodynamic designs, weight reduction, tire substitutions, and auxiliaries improvements. 
- Conduct an assessment of the maintenance interferences of aerodynamic aids on vehicles and conduct competition for operator-friendly designs.

- Apply modern computational fluid dynamics codes to "internal" flows in the radiators/engine compartment and identify new configurations to reduce this element of aerodynamic drag. Follow analysis with design and experimental verification.

- Conduct design and tests of lightweight vehicle structures which appear to be promising by the systems analysis.

- Work with the Department of Transportation and the American Trucking Association to conduct further assessments of the issues surrounding use of super single tires. Conduct a defining set of tests on the relative road damage of dual and single tires.

\section{Emissions}

\section{a. Status of Technology}

In addition to improvements in thermal efficiency, Class $7 \& 8$ diesel engine emissions must also be reduced. When the EPA first began regulating diesel emissions in the mid-to-late 1970 's, trucks typically had emission values of $10-15 \mathrm{~g} / \mathrm{bhp}-\mathrm{hr}$ of NOx and $1 \mathrm{~g} / \mathrm{bhp}-\mathrm{hr}$ of particulates. Over the past twenty years engine manufacturers have made significant improvements by retarding fuel injection timing, increasing the injection pressure, and other design changes (see Figure 6). Also, lower fuel sulfur levels were mandated to reduce particulates. Today's heavy-duty diesel engines emit just under $5 \mathrm{~g} / \mathrm{bhp}-\mathrm{hr}$ of NOx ${ }^{(12)}$ and $0.10 \mathrm{~g} / \mathrm{bhp}$-hr of particulates ( $<0.05 \mathrm{~g} / \mathrm{bhp}-\mathrm{hr}$ for transit buses). In spite of these reductions, there continues to be concern about environmental and health effects of diesel engine emissions; in particular, concern has been expressed recently about the health effects of particulates. Current legislation mandates a reduction of NOx levels to $4 \mathrm{~g} / \mathrm{hhp}-\mathrm{hr}$ by 1998. The EPA and major engine manufacturers have issued a "Statement of Principles" (13) that requires further reduction to $0.05 \mathrm{~g} / \mathrm{bhp}$-hr particulates and $2.4 \mathrm{~g} / \mathrm{bhp}$-hr of NOx plus nonmethane hydrocarbons (NMHC) or $2.5 \mathrm{~g} / \mathrm{bhp}$-hr of NOx plus NMHC with a maximum of 0.5 g/bhp-hr of NMHC by 2004. The Department of Energy's Office of Health and Environmental Research and the Office of Heavy Vehicle Technologies have initiated a study of health issues associated with new engine technologies. Meeting the stringent emission standards set forth in the "Statement of Principles" while, at the same time improving engine efficiency, constitutes a major challenge for diesel engine manufacturers. To address these challenges one can consider three approaches: (1) minimizing the pollutants coming out of the engine (engine-out emissions), (2) cleaning the engine emissions to an acceptable level 
before exhausting to the environment (exhaust aftertreatment), and (3) developing fuel reformulations or additives.

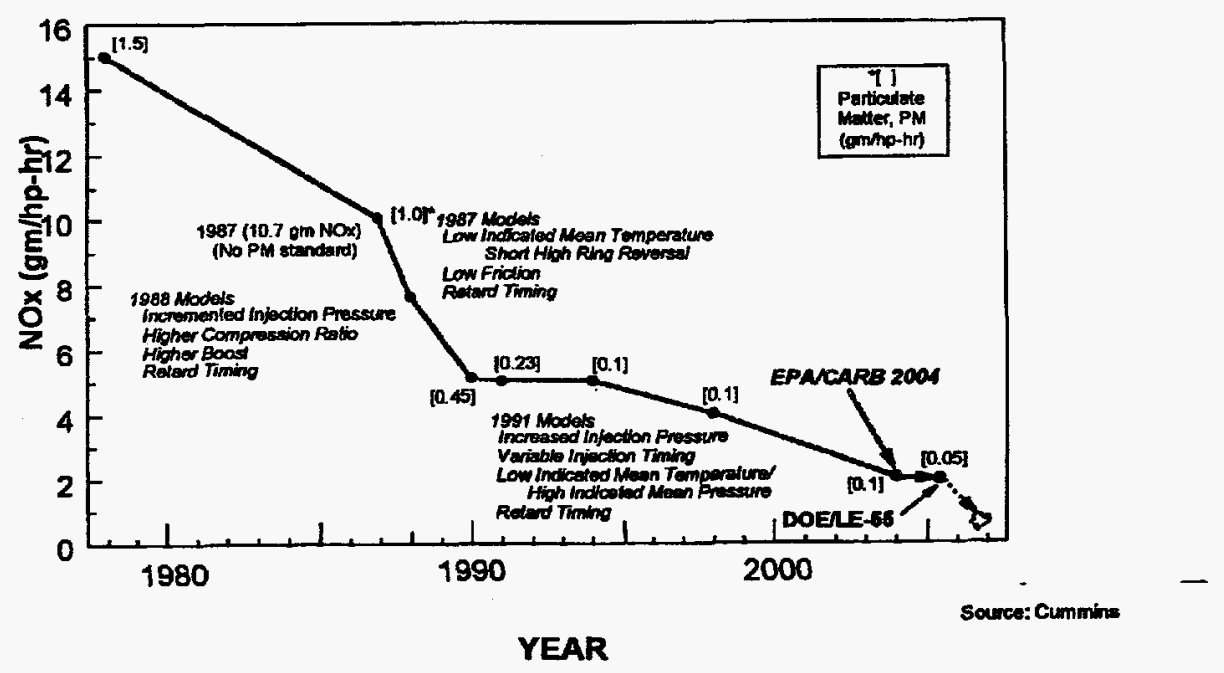

Figure 6. Evolution of Heavy Duty Diesel Cycle Engine Emissions Control.

Engine-out emissions - Optimizing fuel combustion. Significant reductions in emissions have been made through combustion modifications (e.g., retarded injection timing, increased injection pressure and lower temperatures); however, further reductions are needed. The key is an improved understanding of the diesel combustion and emissions formation processes and the development of design tools (i.e., models) which incorporate that understanding and allow engine designers to rapidly explore alternative combustion system designs. Although much progress has been made in understanding and modeling diesel combustion, the level of detailed understanding of the mechanisms by which various engine and injector parameters control combustion and emissions needed by engine designers to make further improvements is not available. Recent work has led to the development of new diagnostics that are providing this detailed understanding.

Lubricant control. Particulate emissions from diesel engines originate from lube oil as well as from fuel combustion. Although this effect is markedly less, it is nonetheless important if the new, more stringent regulations are to be met. To illustrate the magnitude of the particulate contribution from lube oil, a recent study of fuel effects in a light-duty engine resulted in about 5 percent of the total particulate emissions originating from the lube oil, while in a heavy-duty engine the number was about 10 percent ${ }^{(14)}$ However, this value is very engine specific and the particulate contribution from lube oil can range from a few percent to as much as 30 percent of the total particulate emissions. ${ }^{(15)}$ Efforts continue to quantify the effect and means 
to minimize lube oil contribution to particulate emissions while maintaining adequate engine lubrication.

Fuel reformulations and additives. To reach the goal of lower emissions while maintaining efficiency, fuel quality standards must remain high. Fuel reformulations and additives can lead to lower exhaust emissions, better fuel economy and improved cold start performance. Additives can also be used to improve lubricity in low-sulfur fuels. Efforts are underway to understand the efficiency of different additives and their optimum use.

Exhaust aftertreatment - Various concepts are being pursued that could potentially impact both NOx and particulates but still require significant development before they could be considered ready for commercial use. One is the development of a catalyst that can treat the exhaust resulting from the lean combustion conditions; and another is the application of a non-thermal plasma to clean the exhaust; a third technology under development is that of a particulate trap.

Lean-burn catalysts. Catalytic systems in today's automobiles operate with air/fuel ratios at or close to stoichiometric, in which both NOx reduction and $\mathrm{CO}$ and hydrocarbon oxidation can be accomplished in a single catalyst bed, i.e., sufficient reducing gases are present to reduce NOx and enough oxygen is available to oxidize the $\mathrm{CO}$ and hydrocarbons. Diesels, however, operate under lean conditions such that conventional catalysts are not effective. Therefore, new catalysts are required. This is an active area of research and development in which many promising ideas are being pursued in engine manufacturing companies around the world.

Pulsed plasma catalysis. In pulsed plasma systems, short electrical discharges are used to create a plasma that contains electrons, ions, and radicals that are in turn used to reduce NOx and oxidize hydrocarbons. However, such a system working alone is very energy intensive and primarily oxidative and, therefore, not attractive for NOx reduction. Plasma-assisted catalysis offers the potential of enhanced performance over unassisted lean-NOx catalysis. Potential benefits are: more efficient ( 80 percent) NOx reduction; much broader operating temperature range; and less noble metal content.

Particulate traps. For commercial usage a particulate filter must: 1) filter carbon particulates from a high temperature diesel exhaust gas at an acceptable backpressure; 2) survive thousands of thermal transients due to regeneration or cleaning of the filter by oxidizing the collected carbon; 3 ) be durable and reliable over the life of the filter which is in excess of 300,000 miles $(10,000$ hours); and 4) provide a low overall operating cost which is competitive with other filtering techniques. State-of-the-art systems for trapping carbon particulates and regenerating the trap have major deficiencies. Particulate traps are costly, result in fuel consumption penalties, and 
have not demonstrated the reliability and durability required for medium and heavy duty diesel engines.

An alternative aftertreatment for particulates is the use of plasma devices (see previous section) which have shown fair potential for particulate destruction in preliminary tests.

\section{b. Technical Targets}

The emissions targets are: $0.05 \mathrm{~g} / \mathrm{bhp}$-hr of particulates and $2.4 \mathrm{~g} / \mathrm{bhp}-\mathrm{hr}$ of NOx plus non-methane hydrocarbons (NMHC) or $2.5 \mathrm{~g} / \mathrm{bhp}-\mathrm{hr}$ of NOx plus NMHC with a maximum of $0.5 \mathrm{~g} / \mathrm{bhp}-\mathrm{hr}$ of NMHC or less by the year 2004, while achieving the efficiency goals.

\section{c. Barriers}

The barriers to achieving the technical targets for reduced Class $7 \& 8$ emissions are given in Table 4.

Table 4. Summary of Goals, Technical Targets, and Barriers for Class $7 \& 8$ Emissions

\begin{tabular}{|c|c|c|}
\hline Goals & Technical Targets & Barriers \\
\hline $\begin{array}{l}\text { Minimize engine- } \\
\text { out emissions }\end{array}$ & $\begin{array}{l}0.05 \mathrm{~g} / \mathrm{bhp}-\mathrm{hr} \text { particulates } \\
2.4 \mathrm{~g} / \mathrm{bhp}-\mathrm{hr} \mathrm{NOx}+\mathrm{NMHC} \\
\text { or } \\
0.05 \mathrm{~g} / \mathrm{bhr}-\mathrm{hr} \text { particulates } \\
2.5 \mathrm{~g} / \mathrm{bhp}-\mathrm{hr} \mathrm{NOx}+\mathrm{NMHC} \text { with } \\
\text { maximum of } 0.5 \mathrm{~g} / \mathrm{bhp}-\mathrm{hr} \text { NMHC }\end{array}$ & $\begin{array}{l}\text { NOx/soot trade off, that is, } \\
\text { maintaining efficiency and keeping } \\
\text { soot down. } \\
\text { Meeting the target across the load } \\
\text { and speed map. Reliability. } \\
\text { Limitations on cost-effective fuel } \\
\text { additives and reformulation. }\end{array}$ \\
\hline $\begin{array}{l}\text { Develop effective } \\
\text { aftertreatment }\end{array}$ & $\begin{array}{l}0.05 \mathrm{~g} / \mathrm{bhp}-\mathrm{hr} \text { particulates } \\
2.4 \mathrm{~g} / \mathrm{bhp}-\mathrm{hr} \mathrm{NOx}+\mathrm{NMHC} \\
\text { or } \\
0.05 \mathrm{~g} / \mathrm{bhr}-\mathrm{hr} \text { particulates } \\
2.5 \mathrm{~g} / \mathrm{bhp}-\mathrm{hr} \mathrm{NOx}+\mathrm{NMHC} \text { with } \\
\text { maximum of } 0.5 \mathrm{~g} / \mathrm{bhp}-\mathrm{hr} \text { NMHC }\end{array}$ & $\begin{array}{l}\text { Development of lean combustion } \\
\text { catalyst. Cost effectiveness. } \\
\text { Durability/reliability }\end{array}$ \\
\hline
\end{tabular}




\section{d. Technical Approach}

Meeting the technical targets for emissions will require the three-pronged diesel engine emission control strategy described in Figure 7, i.e., understanding and optimizing in-cylinder combustion processes, optimizing fuel formulation, and developing exhaust aftertreatment technologies, such as improved catalysts. Specific R\&D tasks are:

- Apply advanced diagnostics to describe and quantify (when possible) the incylinder formation of NOx and soot.

- Develop advanced fuel injection systems, including high strength, non-galling, wear-resistant materials for increased injection pressure and reduced particulate emissions.

- Reduce or eliminate particulate contributions from lube oil by development of advanced solid lubrication materials for use in valve guides. Investigate operation of valve guides without liquid lubrication.

\section{Multifaceted Emission Control Approach Necessary to Ensure That Fuel Economy, Costs, and Durability Goals Are in Harmony with Ambitious Emission Targets}

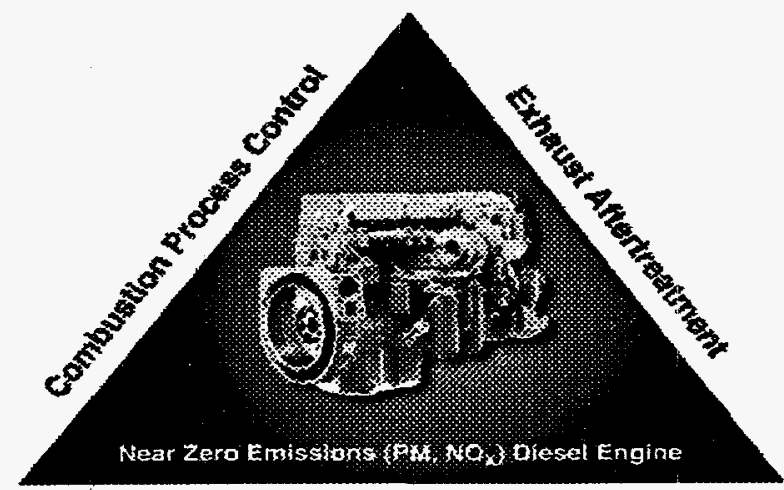

Fuel Formulation

Figure 7 
- Develop advanced materials, designs, and regeneration technologies for particulate traps.

- $\quad$ Evaluate effectiveness of varying amounts of exhaust gas recirculation (EGR).

- Determine effectiveness of fuel injection rate shaping. This will be fuel injector specific and will require integration with sensors and controls.

- Develop fuel additives and compare effectiveness of fuel additives and reformulated diesel fuel to baseline fuel.

- Characterize fuel injector sprays that provide optimum combustion parameters.

- Formulate new, cost-effective catalysts that reduce NOx in lean combustion environments.

- Evaluate effective catalyst formulations for longevity and stability to meet 300,000 mile requirement.

- Plasma-assisted catalysis has been demonstrated on simulated exhaust and a slipstream of real diesel engine exhaust. Efforts are required to evaluate the scale-up to high gas flow rates.

- Conduct experimental and modeling program to form a better understanding of the chemical and physical mechanisms of plasma-assisted catalysis.

- Conduct studies of health effects of new engine technologies.

\section{Fuel Flexibility}

In order to successfully achieve DOE-OTT's goal to reduce the nation's reliance on imported oil, it is important that alternative fuels, which may include natural gas, diesel fuel from natural gas (Fischer-Tropsch), liquefied petroleum gas, ethanol, methanol, dimethyl ether (DME), diethyl ether (DEE) and biodiesel, be utilized in Class $7 \& 8$ vehicles. This section discusses the possibility of using these fuels in this application and some of the barriers that must be overcome. The Heavy Vehicle Technologies program strategy focuses on the diesel engine with a future direction to run these engines on liquid alternative fuels in a flexible-fuel mode, or on gaseous fuels in a dedicated mode.

Each of the Class $7 \& 8$ engine manufacturers has in production engines designed to operate on alternative fuels. This program will extend the work of these manufacturers to the development of liquid flexible fuel engines and optimized gaseous fuel engines. 


\section{a. Status of Technology}

Alternative fuels can displace diesel fuel in Class $7 \& 8$ trucks; however, except for biodiesel, and "synthetic" diesel fuel, they cannot be directly substituted without substantial engine modifications. With current technology, the optimum efficiency and emissions can only be achieved with engines that are optimized for each fuel. The heavy duty engine development that has been done on each of the alternative fuels is as follows:

- Alcohol fuels (methanol and ethanol)

- Direct injection with glow-plug assisted ignition. Near-diesel efficiency has been achieved.

- Direct injection with cetane improver. Near-diesel efficiency has been achieved.

- $\quad$ Fumigation with diesel injection for ignition and part-load operation. This approach has lower efficiency than a dedicated diesel engine and uses a significant amount of diesel fuel.

- $\quad$ Gaseous fuels (natural gas and propane)

- $\quad$ Carbureted/fuel injected, throttled spark ignition (SING). Overall efficiency 10-15 percent lower than diesel.

- $\quad$ Fuel injected, unthrottled, with pilot diesel injection for ignition and part load operation (PING). Near diesel efficiency has been achieved.

- Direct injection (DING) with glow-plug assisted ignition. Near diesel efficiency has been achieved. (Substantial research and development; not developed for production.)

- $\quad$ Biodiesel blends

- $\quad$ Normal diesel operation with essentially no major engine changes required. Efficiency near or equal diesel efficiency.

- Dimethyl Ether (DME)

- Direct injection with minor changes other than injection system. Efficiency near or equal to diesel efficiency. (Substantial research and development; not developed for production.)

- Diethyl Ether (DEE)

- $\quad$ A limited amount of work on DEE appears in the literature, primarily relating to basic properties as an engine fuel. DEE has excellent auto ignition properties and can be made as a derivative from the biomass ethanol process. 
Over the past several years, the Department of Energy has been actively working with the heavy vehicle engine manufacturers to develop alternative fuel engines and to evaluate their effectiveness in real-world applications. For example, Caterpillar has an ongoing research project, supported in part by the Department of Energy, involving the development of a methanol/diesel flexible-fuel heavy-duty engine.

Most alternative fuel heavy-duty engines being offered today run on natural gas. These engines are primarily used in city buses and garbage packers. The two approaches that are being used in production engines today are outlined below.

1. Spark ignited natural gas (SING). These engines are usually based on a diesel engine block but are converted to spark ignition. Cummins, Detroit Diesel, Caterpillar, and John Deere each have engines of this type in production. The Cummins, Detroit Diesel, and John Deere engines use a lean-burn strategy. At full load, the lean-burn spark ignition engines reach near diesel efficiency; however, at idle and part load conditions, their efficiency is significantly less than a diesel engine. The Caterpillar natural gas engine is stoichiometric. Caterpillar also offers a spark ignited, stoichiometric propane engine.

2. Dual-fuel pilot ignition natural gas (PING). This approach maintains the diesel cycle and uses a small charge of diesel fuel to ignite the natural gas. At idle and low load conditions these engines burn mostly diesel fuel; at full load they burn up to 95 percent natural gas. These engines can be run on diesel only, but cannot be run on natural gas only, since they use a pilot charge of diesel to ignite the natural gas. Caterpillar is now developing a full line of dual-fuel diesel/natural gas heavy-duty engines. In addition to natural gas, several manufacturers are planning on offering propane heavy-duty engines in the near future. The propane engines will be spark ignited or diesel pilot ignition design.

With respect to fuel storage of natural gas, current systems either store it as a compressed gas at pressures up to 3,600 psi, or as a cryogenic liquid. High pressure tank development has resulted in lighter tanks in the past few years, and efforts are underway to lower the cost of these tanks. In addition, DOE sponsors work on developing effective adsorption media to store natural gas at low pressures.

Direct injected, glow-plug ignition assisted alcohol fueled engines have been produced for several years by Detroit Diesel Corporation. Hundreds are in service, primarily in transit bus fleets. 


\section{b. Technical Targets}

The primary targets are:

1. Fuel flexibility and a thermal efficiency of over 50 percent with liquid alternative fuels, and

2. A thermal efficiency of over 50 percent with dedicated gaseous fuel engines

Both targets are at model year 2004 government/industry "Statement of Principles" emissions levels.

With regards to the fuel-flexibility target, the difficulty of designing an engine that can burn more than one fuel varies with the combinations of fuels chosen. The following is a brief description of the issues involved.

Conventional spark ignition engines require higher octane fuels, such as gasoline, alcohols, natural gas, and propane. Low octane fuels cause detonation problems in these engines.

Conventional diesel engines require fuels with higher cetane ratings (which self-ignite), such as diesel, biodiesel, and DME/DEE. Higher octane fuels have low cetane ratings, and conventional diesels cannot operate with these fuels unless cetane improvers (such as Avocet) are added to the fuel, or an ignition source is incorporated into the engine. Ignition sources which have been used include spark plugs, glow plugs, and pilot injection of diesel fuel (which self ignites and ignites the low cetane fuel). With these approaches, a high octane/low cetane fuel can be utilized in diesel cycle engines with efficiencies near those achieved with diesel fuel.

Differences in heating value (quantity of fuel required), lubricity, viscosity, spray characteristics, heat of vaporization, vapor pressure, beginning and end boiling points, etc., in addition to self-ignition characteristics, add further complications to achieving good efficiency and low emissions with multiple fuels in the same engine. However, this is certainly achievable with some fuel combinations, such as with diesel and biodiesel, with few changes required.

DME/DEE could conceivably be utilized in a "fairly conventional" diesel type engine (without ignition source addition) if fuel storage system, injection, and control challenges can be satisfactorily handled.

Finally, a variety of higher octane liquid fuels (alcohols, gasoline) could be utilized in a diesel type engine with ignition source addition, with challenges to be met in ignition system as well as fuel injection/control.

Tables 5 and 6, respectively, summarize the specific targets for each engine parameter for the liquid flexible-fuel engine and the dedicated gaseous fuel engine. 
Table 5. Summary of Technical Targets and Barriers for Class $7 \& 8$ Liquid Fuel-Flexible Engine

\begin{tabular}{|c|c|c|c|}
\hline $\begin{array}{c}\text { Engine } \\
\text { Parameter }\end{array}$ & Current Practice & Target & Barrier \\
\hline Cost & $\begin{array}{l}\text { No fuel-flexible engine } \\
\text { available now }\end{array}$ & $\begin{array}{l}\text { Depends upon fuel } \\
\text { combination }\end{array}$ & $\begin{array}{l}\text { Extra electronics cost, cost to } \\
\text { upgrade materials, extra cost of } \\
\text { components including fuel tanks, } \\
\text { lines, etc. Need for low cost, } \\
\text { reliable fuel sensors. Acceptance } \\
\text { by market place of any cost } \\
\text { penalty. }\end{array}$ \\
\hline Efficiency & $\begin{array}{l}\text { Maximum efficiency of } 39 \\
\text { percent (for dedicated } \\
\text { methanol engine) }\end{array}$ & 55 percent by 2004 & $\begin{array}{l}\text { Same barriers as for a high } \\
\text { efficiency diesel engine, plus } \\
\text { optimum combustion chamber, } \\
\text { compression ratio, injection rate, } \\
\text { spray hole size and number, etc. } \\
\text { are generally different for fuels of } \\
\text { different viscosity, heating values, } \\
\text { cetane number, heat of } \\
\text { vaporization, etc. }\end{array}$ \\
\hline Emissions & $\begin{array}{l}\text { Dedicated methanol heavy } \\
\text { engines were certified to } \\
1992 \text { standards: } \\
\text { NOx }<5.0 \text { g/bhp-hr } \\
\text { HC }<1.3 \text { g/hhp-hr } \\
\text { CO }<15.5 \text { g/bhp-hr } \\
\text { PM }<0.25 \text { g/bhp-hr }\end{array}$ & $\begin{array}{l}\text { NMHC }+ \text { NOx } \\
=2.4 \mathrm{~g} / \mathrm{bhp}-\mathrm{hr} \text { or } \\
\text { NMHC }+\mathrm{NOx} \\
=2.5 \mathrm{~g} / \mathrm{bhp}-\mathrm{hr} \text { and } \\
\text { NMHC cap of } \\
0.5 \mathrm{~g} / \mathrm{bhp}-\mathrm{hr}\end{array}$ & $\begin{array}{l}\text { Difficulty in optimizing emissions } \\
\text { control strategies for more than } \\
\text { one fuel. Geometrically fixed } \\
\text { combustion system characteristics } \\
\text { will tend to compromise emissions } \\
\text { due to fuel property differences. } \\
\text { (Similar to the efficiency barriers } \\
\text { listed above.) }\end{array}$ \\
\hline Reliability & $\begin{array}{l}\text { No fuel-flexible engine } \\
\text { now }\end{array}$ & $\begin{array}{l}\text { Essentially same as } \\
\text { diesel. }\end{array}$ & $\begin{array}{l}\text { The additional components and } \\
\text { complexity required for multi-fuel } \\
\text { capability tends to reduce } \\
\text { reliability. Materials compatibility } \\
\text { with multiple fuels is also a } \\
\text { reliability issue. }\end{array}$ \\
\hline
\end{tabular}


Table 6. Summary of Technical Targets and Barriers for Class 7 \& 8 Dedicated Gaseous Fuel Engine

\begin{tabular}{||l|l|l|l||}
\hline Engine Parameter & \multicolumn{1}{|c|}{ Current Practice } & Target & Barrier \\
\hline Cost & $\begin{array}{l}\text { 15 percent to } 100 \text { percent } \\
\text { more than a diesel engine }\end{array}$ & Same as diesel engine & $\begin{array}{l}\text { Current production } \\
\text { volumes are low. Fuel } \\
\text { storage system cost are } \\
\text { high. Added components } \\
\text { and complexity add cost. }\end{array}$ \\
\hline Efficiency & $\begin{array}{l}\text { Maximum of 37 percent } \\
\text { with lean-burn SING, 15 } \\
\text { percent less efficient than } \\
\text { diesel in the field with } \\
\text { SING engines, } 4 \text { percent } \\
\text { less than diesel with pilot } \\
\text { ignition natural gas. }\end{array}$ & 55 percent by 2006 & $\begin{array}{l}\text { Same barriers as for a } \\
\text { high efficiency diesel } \\
\text { engine, plus low cetane } \\
\text { rating of fuel makes diesel } \\
\text { cycle difficult. May need } \\
\text { low-cost fuel sensors or } \\
\text { other means to detect fuel } \\
\text { quality variations. }\end{array}$ \\
\hline Emissions & $\begin{array}{l}\text { Dedicated lean-burn NG } \\
\text { spark ignited engine: } \\
\text { NOx=1.4 g/bhp-hr } \\
\text { NMHC }=0.5 \mathrm{~g} / \mathrm{bhp}-\mathrm{hr} \\
\text { CO }=6.0 \mathrm{~g} / \mathrm{bhp}-\mathrm{hr} \\
\text { PM=0.03 g/bhp-hr }\end{array}$ & $\begin{array}{l}\text { NMHC+NOx } \\
=2.4 \mathrm{~g} / \mathrm{bhp}-\mathrm{hr} \text { or } \\
\text { NMHC }+\mathrm{NOx} \\
=2.5 \mathrm{~g} / \mathrm{bhp}-\mathrm{hr} \text { and } \\
\text { NMHC cap of } \\
0.5 \mathrm{~g} / \mathrm{bhp} \text {-hr }\end{array}$ & $\begin{array}{l}\text { Maintaining low } \\
\text { emissions while } \\
\text { increasing efficiency. }\end{array}$ \\
\hline Reliability & $\begin{array}{l}\text { Similar to diesel. } \\
\text { Same as diesel. }\end{array}$ & $\begin{array}{l}\text { Spark plug life (if SI), } \\
\text { fuel delivery system } \\
\text { reliability, valve/valve } \\
\text { seat wear. }\end{array}$ \\
\hline
\end{tabular}




\section{c. Barriers}

Barriers to achieving the liquid flexible-fuel and dedicated gaseous-fuel engines are given in Tables 5 and 6, respectively. The primary barrier is probably a market barrier and not a technical one. Because of their additional cost and complexity, an incentive, such as lower alternative fuel cost or perceived threat of a fuel shortage will be required to create a market for fuel-flexible engines.

Other barriers have more to do with the vehicle than with the engine. The weight of the vehicle can be a barrier due to the extra components required on the engine as well as additional fuel tanks. Any increase in weight reduces load carrying capacity. If extra fuel tanks are required the space availability on the vehicle for the extra tanks can also be a barrier. Insufficient fueling infrastructure is also a barrier to alternative fuel use.

\section{d. Technical Approach}

Liquid fuel-flexible engine. There are no liquid fuel-flexible heavy-duty engines available now. This program will support the research needed to develop one and address the barriers to developing a commercially viable liquid fuel-flexible truck. Specific elements of the technical approach to overcoming the barriers outlined in Table 5 are listed below:

- Conduct basic research on alternative fuels to better understand the combustion process.

- Support research and development targeted at creating a high efficiency engine capable of burning two different fuels. Work may include variable valve timing, EGR, skip firing, Miller cycle, ${ }^{(19)}$ lowering the lean limit, ignition enhancement techniques and advanced sensor and control systems or other approaches shown worthy of pursuit.

- Conduct combustion research on alternative fuels.

- $\quad$ Reduce engine out emission with techniques such as lowering combustion temperature, EGR, and systems. Develop lean-burn NOx catalytic converter for exhaust aftertreatment.

- Develop fuel tanks compatible with both diesel fuel and the liquid alternative fuel.

- Support R\&D to increase the reliability and durability of key components of the flexible-fuel system. 
- Develop low cost, durable materials for flexible-fuel systems which are compatible with both diesel fuel and the alternative fuel.

- Develop stable, corrosion-resistant materials and designs for glow plugs.

- Investigate low cost additives to increase the lubricity of alternative fuels.

- Make low cost a priority on all development projects. Identify technology that overcomes the other barriers at the lowest cost.

Gaseous fuel engine. Gaseous fuel truck engines are available now; however, most of these engines are significantly less efficient than comparable diesel engines. The program will focus on improving the efficiency of these engines. Specific elements of the technical approach to overcoming the barriers outlined in Table 6 are listed below.

- $\quad$ Research and development targeted at improving the efficiency of dedicated gaseous fuel engines. Work may include variable valve timing, EGR, skip firing, Miller cycle, ${ }^{(1)}$ extend lean limit, advanced control systems, direct injection, micro-pilot injection, or other approaches shown worthy of pursuit.

- Develop fuel sensor or other technology to detect fuel quality variations.

- Develop durable, wear- and corrosion-resistant intake valves, valve seats, and valve guides of advanced materials to increase durability of natural gas engines.

- $\quad$ Address emissions impacts with each development step.

- Develop safe, lightweight, low-cost cylinders, fuel tanks, and fuel storage media.

- Develop durable, low-cost ignition systems.

B. CLASS 3 - 6 TRUCKS - No specific technology development is planned for Class 3-6 Trucks. It is expected that the technology developed for Class 7 \& 8 trucks will devolve downward to Class 3-6 trucks as the market dictates. Some of the technology to be developed for Class $1 \& 2$ trucks described in the following sections might also find its way into Class 3-6 trucks.

C. CLASS $1 \& 2$ TRUCKS - The following sections describe the goals for Class 1 \& 2 trucks, the status of technology for these trucks, the technical targets to be achieved 
in order to meet these goals, the technical barriers which must be overcome to achieve . the technical targets, and the technical approach to overcoming those barriers.

\section{Goals}

The Program goal with respect to Class $1 \& 2$ trucks is to develop by 2004 the enabling technology to encourage significant dieselization of Class $1 \& 2$ trucks, thereby achieving at least a 35 percent fuel efficiency improvement over gasoline-fueled engines for these vehicles, while at the same time meeting required federal and state emission requirements.

2. $35 \%$ Fuel Efficiency Improvement - $45 \%$ Efficiency Diesel Engine

a. Status of Technology

A sampling of data for direct injection (DI) diesels of approximate size and power for light trucks gives a range of efficiencies at peak power of 38-42 percent (See Table 7). The sample includes high-speed diesels from Europe as well as heavy duty diesels used in large pickups. Of course over the Federal Test Procedures (FTP) fuel economy and emissions test cycle, these engines operate most of the time at lower efficiency than this, but still much better than spark ignition (SI) engines. Preliminary simulations show that diesels in this range could improve vehicle fuel economy by the 35 percent (or more) selected as the program goal. As a reference, there is only the General Motors (GM) indirect injection (IDI) diesel that is emission certified as a light truck, and it achieves 10-15 percent better mpg than SI engine versions of the same vehicle. In general, the latest IDI engines have peak efficiencies around 35 percent compared to $41-42$ percent for the latest small DI engines.

The minimum standard engine power in a full-size pickup is $108 \mathrm{~kW}(145 \mathrm{hp})$, with optional engines capable of about $215 \mathrm{~kW}(288 \mathrm{hp})$. The trend is toward higher powered engine offerings.

\section{b. Technical Targets}

Fuel conservation will occur by the dieselization strategy only if:

1. An efficient diesel engine suitable for Class $1 \& 2$ trucks is made emissionslegal to offer for sale.

2. The diesel option is attractive to consumers so they will select it over less efficient SI engines. 
Table 7. Key Efficiency-Related Characteristics of Engines of Approximate Size and Power for Class 1 \& 2 Trucks

\begin{tabular}{||l|l|l|l||}
\hline \multicolumn{1}{|c|}{$\begin{array}{c}\text { Engine } \\
\text { Characteristic }\end{array}$} & \multicolumn{1}{|c|}{$\begin{array}{c}\text { Present } \\
\text { Automotive } \\
\text { Diesel }\end{array}$} & \multicolumn{1}{|c|}{$\begin{array}{c}\text { Present Automotive SI } \\
\text { Engine }\end{array}$} & $\begin{array}{c}\text { Present } \\
\text { Heavy Duty Diesel }\end{array}$ \\
\hline $\begin{array}{l}\text { Best Full Load } \\
\text { Thermal Efficiency } \\
\text { (percent) }\end{array}$ & 41 & 26 & 43.3 \\
\hline $\begin{array}{l}\text { Best Thermal } \\
\text { Efficiency (percent) }\end{array}$ & 42.8 & 34 & 46.5 \\
\hline $\begin{array}{l}\text { Peak Mean } \\
\text { Effective Pressure } \\
\text { (max) (kPa) }\end{array}$ & Up to 1400 & $\begin{array}{l}800-1100 \\
\text { (non-turbo) }\end{array}$ & Up to 1900 \\
\hline $\begin{array}{l}\text { Power Specific } \\
\text { Weight (kg/kW) }\end{array}$ & 2.0 & 1.1 & 3.6 \\
\hline $\begin{array}{l}\text { Mean piston speed, } \\
\text { rated power } \\
\text { (typical) (m/s) }\end{array}$ & $12.0-13.0$ & $12.0-15.0$ & 8.0 \\
\hline Compression Ratio & $19.0-21.0$ & $9.5-10.0$ & $15.0-17.5$ \\
\hline
\end{tabular}

Technical targets and barriers for a high-efficiency diesel that would be rapidly implemented in pickups and sport utility vehicles (SUVs) are summarized in Table 8. The principal efficiency target is to operate at over 40 percent efficiency through a wide range of loads and speeds. While diesel efficiency does not drop as markedly at light loads as in SI engines, the low-power duty cycle of pickups and SUVs calls for more emphasis on light-load efficiency than for Class $7 \& 8$ trucks. In the light duty vehicle FTP emissions/fuel economy driving cycle, a typical SUV will consume nearly 90 percent of its fuel with the engine operating at less than $30 \mathrm{hp}$. Most improvements to the engine that boost peak power efficiency will also help part-load efficiency. Power-specific weight of the engine should be reduced in order to maintain vehicle power requirements at present levels.

\section{c. Barriers}

The principal barriers (other than emissions, covered in the next section) to be overcome for dieselizing Class $1 \& 2$ vehicles are the engine's cost, plus some nontechnical barriers such as market perceptions. Although pricing practice does not always reflect cost, the diesel 
Table 8. Summary of Pickup/SUV Diesel Engine Targets and Barriers

\begin{tabular}{|c|c|c|c|}
\hline Engine Parameter & Current Practice & Target & Barrier \\
\hline Efficiency ( percent) & $\begin{array}{l}38-42 \text { percent } \\
\text { DI diesels, } 80-150 \mathrm{~kW} \text {, } \\
\text { maximum }\end{array}$ & $\begin{array}{l}\text { Up to } 45 \text { percent peak, } \\
\text { with adequate part } \\
\text { load efficiency for } 35 \\
\text { percent better vehicle } \\
\text { mpg }\end{array}$ & $\begin{array}{l}\text { Need high bmep and low } \\
\text { friction losses at part loads }\end{array}$ \\
\hline $\begin{array}{l}\text { Power-Specific } \\
\text { Weight (kg/kW) }\end{array}$ & $\begin{array}{l}\text { Gasoline-1.1 } \\
\text { Auto Diesel-2.0 } \\
\text { Heavy Diesel-2.5 and up }\end{array}$ & 2.0 & $\begin{array}{l}\text { Current designs using } \\
\text { lightweight materials have } \\
\text { inadequate strength for } \\
\text { diesel cylinder conditions. } \\
\text { Diesel requires turbocharger } \\
\text { and extra fuel system } \\
\text { components. Inherent } \\
\text { limitations on speed. }\end{array}$ \\
\hline Cost $(\$ / k W)$ & & $\begin{array}{l}\text { Overall cost } \\
\text { competitive with SI } \\
\text { engines }\end{array}$ & $\begin{array}{l}\text { Cost of fuel-injection system } \\
\text { and air-handling system. } \\
\text { Relatively limited volume of } \\
\text { production. }\end{array}$ \\
\hline Durability (Miles) & & $\begin{array}{l}\text { Greater than SI } \\
\text { engines of similar } \\
\text { application }\end{array}$ & \\
\hline $\begin{array}{l}\text { Emissions } \\
\text { NOx (g/mi) } \\
\text { HC } \\
\text { CO } \\
\text { PM }\end{array}$ & $\begin{array}{l}0.15-0.20 \text { (SI) } \\
\text { equal to or much greater } \\
\text { than } 1.5 \text {, diesel pickup } \\
0.20, \text { SI or CI } \\
1.5, \text { SI or CI } \\
0.08, \text { CI auto }\end{array}$ & $\begin{array}{l}0.50 \\
\\
0.07 \\
2.8 \\
0.04\end{array}$ & $\begin{array}{l}\text { See Emissions } \\
\text { Section }\end{array}$ \\
\hline Noise & $\begin{array}{l}\text { DI diesel powered vehicles } \\
\text { noisier than SI in idle and } \\
\text { acceleration modes }\end{array}$ & $\begin{array}{l}\text { Comparable to today's } \\
\text { gasoline-powered } \\
\text { vehicles }\end{array}$ & $\begin{array}{l}\text { Need more control of fuel } \\
\text { injection and combustion } \\
\text { process, such as by advanced } \\
\text { fuel injection systems. Need } \\
\text { engine system materials and } \\
\text { structures to improve noise } \\
\text { control. }\end{array}$ \\
\hline
\end{tabular}


option, for the few vehicles where it is available, costs at least $\$ 1,000$ more (in some cases much more) than the base gasoline engine. The fuel injection system for diesels, necessarily complex to achieve fine control of injection spray at high pressure, is one of the key cost drivers. The fuel injection system is critical to engine performance, efficiency, and emissions. Further adding to the cost is the air handling system, including the turbocharger, aftercooler, and related hardware that diesels need in order to have competitive power density and responsiveness.

Generally, due to its constraints on engine speed and necessarily more robust construction, the power-specific weight of the diesel is greater than the SI engine. Therefore, unless improvement (i.e., reduction) of the power-specific weight is achieved, some of its fuel economy advantage will be negated when applied to a Class $1 \& 2$ vehicle.

There are some fundamental barriers to improving engine efficiency at part load, given that the engine must be designed for a peak power roughly five times that at which it most often operates. Mechanical friction, pumping, and heat losses, for example, simply represent a larger fraction of the net engine output at light loads. Fortunately with no need of a throttle for control, the diesel engine has inherent efficiency advantage even at light loads.

\section{d. Technical Approach}

- Develop cost-effective fuel injection systems with precise control of injection characteristics necessary for optimized combustion and low emissions. Analyze possible simplification and cost-savings of fuel system if effective exhaust aftertreament is developed.

- Develop and apply cost-effective manufacturing methods and materials for overall cost reduction of injectors, fuel pumps and fuel injection control systems as well as other key engine components.

- Evaluate and assess new engine/component architectures (e.g., in-line, V-6, V-8, etc.) that would have inherently lower cost than current practice. Take designs to fabrication and test phase as warranted.

- Increase brake mean effective pressure for better power density and efficiency through improved air handling and fuel injection systems. Develop turbochargers with higher efficiency and more flexibility.

- Through improved engine architecture and application of low density materials, further increase engine power-specific weight to a level competitive with SI engines. 


\section{Emissions}

\section{a. Status of Technology}

Emission certification of diesel engines for pickups and sport utility vehicles (SUVs) under 8,500 pounds gross vehicle weight rating (GVWR) is more challenging than certification for heavy trucks because of tiered structure of emissions standards and different test procedures for heavy- and light-duty vehicles. Pickups and SUVs under 8,500 pounds GVWR must be certified as light-duty trucks using the same Federal Test Procedure (FTP) on a chassis dynamometer as for passenger cars. The regulations for NOx and particulates for light-duty trucks are relatively more stringent than those for heavy-duty diesel engines that are certified over the engine dynamometer Federal Transient Test Procedure. The prevailing regulations for light duty trucks are shown in Figure 8. Although not shown in Figure 8, the standards for diesel are somewhat relaxed relative to gasoline fueled vehicles. The EPA is modifying the FTP to incorporate a high acceleration sequence. The new cycle is referred to as "US06" and is potentially critical for diesel-powered vehicles, since it would further exacerbate NOx and particulates over the FTP. Emissions regulations for diesel-powered light-duty vehicles are eventually to merge with those for gasoline vehicles per the Clean Air Act.

The ability to meet emissions regulations for pickups and SUVs appears to be highly variable among commercially available diesel engines. The highly popular DI diesels available in full size pickups are certified as heavy duty diesel engines. They are equipped with oxidation catalysts. Preliminary analysis suggests that these engines, packaged for a smaller vehicle would exceed light duty NOx standards by a factor of three. Hence, application of heavy duty DI diesel technology in a smaller package appears to carry a substantial emissions barrier. One IDI diesel for pickups is certified per light-duty truck standards, but the IDI is a relatively inefficient design. It utilizes EGR plus an oxidation catalyst to comply with standards, but compared to an SI engine in a similar vehicle, it still produces about five times more NOx.

An alternative to downsizing heavy-duty diesel technology may be to scale up passenger car diesels that are much more developed with regard to emission compliance and other attributes such as noise, vibration, and harshness (NVH). Note that many domestic pickups and SUVs are powered by the same basic gasoline engines that are used in passenger cars. Prominent examples are the Ford and GM V-8s. There are only two diesel passenger cars in the U.S. to study as points of departure, the most interesting being the Volkswagen Passat with a turbocharged DI diesel. It meets the present standards for NOx and particulates by a narrow 


\section{Federal Diesel Light Truck Standards for PM and NOx}

1999+

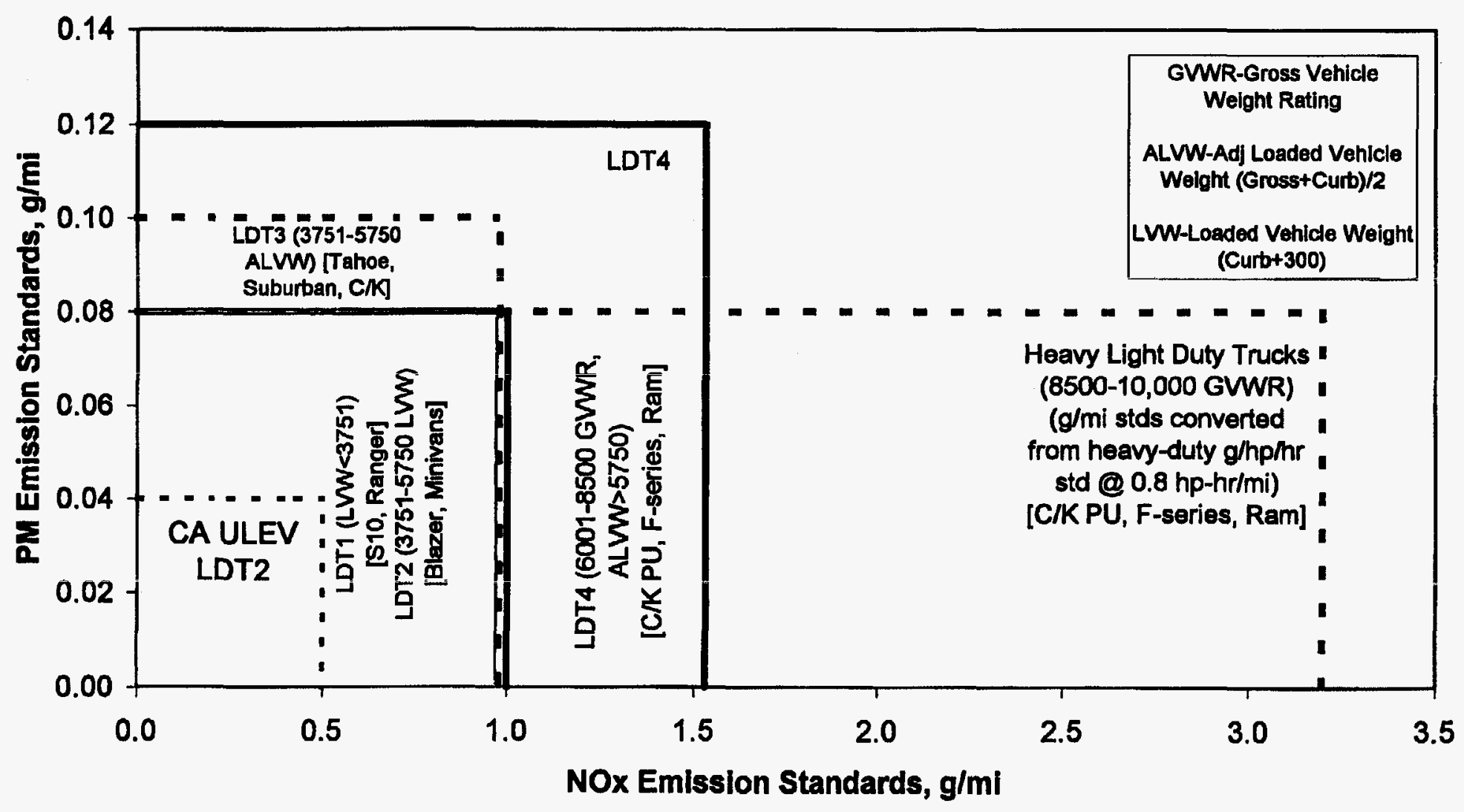

Figure 8 
margin with use of aftertreatment. However, even the five-cylinder version, 2.5 liter, $88 \mathrm{~kW}$, (available only in Europe from Audi) has inadequate power for most pickups and SUVs. Ford and GM European operations have diesels of similar technology, and Detroit Diesel Corporation (DDC) has acquired VM Motori, a supplier of diesels (IDI to date) in Chrysler vehicles in Europe, including Jeeps. The so-called high-speed diesels have well-developed EGR systems and electronic controls that help achieve emissions standards, at least in passenger cars. Larger, heavier SUVs and pickups will require even better emission technology because of the light-duty vehicle test protocol and regulations based on mass emissions per mile. It is evident that future regulations cannot be met without further advances in in-cylinder controls and aftertreatment for NOx and particulates.

\section{b. Technical Targets}

Concerns about the effects of particulates on human health, plus perceptions about smoky diesels suggest that aggressive emissions targets be established for a pickup/SUV engine.

Federal and California regulations for light duty truck emissions were reviewed in depth. The choice of technical target for emissions could range from Tier 2 for passenger cars to accepting at face value the present regulations for 1999+. Electing a "clean diesel" philosophy, the following emissions targets have been selected.

$\begin{array}{ll}\text { NOx- } & 0.5 \mathrm{~g} / \mathrm{mile} \\ \text { NMHC- } & 0.07 \mathrm{~g} / \mathrm{mile} \\ \text { CO- } & 2.8 \mathrm{~g} / \mathrm{mile} \\ \text { Particulates- } & 0.04 \mathrm{~g} / \mathrm{mile}\end{array}$

These are approximately the same as California ULEV for LDT 2, which would capture most of the SUVs and full-size pickups. Phase-in of this standard is to be completed by 2003 . The above targets are still relaxed relative to expected standards for gasoline-fueled passenger cars. New Federal standards for light duty trucks have not been proposed beyond 1999.

\section{c. Barriers}

Achieving NOx and particulates emission regulations with engines of high efficiency and low cost is a significant barrier, particularly in the higher power range necessary for heavy light trucks. For in-cylinder controls, further development of EGR is necessary for heavy-duty diesels if they were to be "scaled down" for pickups. Cooled EGR has not been adequately developed for full commercialization. Present fuel injection systems do not have the characteristics needed for emission control. Aspects of the fuel/air mixing process are still insufficiently understood and modeled to optimize engine design. Additionally, NOx and particulates aftertreatment systems are not sufficiently developed for commercial application. In high-power versions of light duty diesels, challenges will be in achieving significant 
efficiency advantage over gasoline engines and matching the longevity expected from diesel. engines.

\section{d. Technical Approach}

- Through experiments and simulations, develop an improved understanding of fuel-air mixing, including wall effects.

- Develop and apply cooled EGR systems to diesel engines.

- Develop fuel injection components, controls, systems for improved control of fuel injection rate and timing based on improved understanding of phenomena.

- Develop more effective NOx aftertreatment systems with overall 50 percent NOx conversion.

- Develop cost-effective particulate control aftertreatment systems.

- Improve air handling systems, including turbocharger systems, for reduced emissions, including during transients.

- Develop catalyst formulations that enable low light-off temperatures.

- Evaluate effective catalyst formulations for longevity and stability to meet 100,000 mile requirement.

\section{NVH, Odor, and Cold Weather Limitations of Diesels.}

Gasoline engines are currently the accepted standard of the industry for passenger cars and light trucks, especially in the U.S. Therefore, the performance and other operating characteristics of competitive or alternative powerplants, such as diesel engines, are measured against the gasoline engine standard. While the diesel has a recognized advantage over the gasoline engine in fuel efficiency, it is also perceived to have significant relative shortcomings in the areas of: $\mathrm{NVH}$, visible smoke emissions and odor, and low ambient temperature limitations. Some of these shortcomings can be ameliorated through improved design and component development, as described in the next section.

\section{a. Status of Technology}

Engines emit noise through three paths: the exhaust, the intake, and the external walls of the engine proper. The diesel engine, especially in older models, has proven to be noisier and rougher than comparable gasoline engines, primarily with the differences in the combustion process between the two engines. Secondary reasons are found in the mechanical differences 
(the diesel has heavier reciprocating masses), and in the fact that the diesel needs more air for a given power output. The largest difference is to be found in the much higher noise radiated from the walls of diesel engines. The diesel engine requires a fairly high compression ratio to function properly, and that results in much higher cylinder pressures than in an equivalent gasoline engine. Higher pressures cause bigger excitation (deformation) of the block and head, resulting in higher noise radiation from the engine (external) walls. In addition, the heterogeneous diesel engine combustion process is noisier as well, with its much higher rate of pressure rise. The faster rising pressure in the cylinder also causes stronger torsional vibrations, which accounts for part of the perceived roughness of diesels.

The noise generation phenomena in diesel engines has been well understood for some time, but diesel manufacturers could do little about it because of severe limitations with the fuel injection equipment (FIE). Until very recently, most diesel FIE used mechanical or hydraulic governors, so control of injection events was very limited. As a result, most engines exhibited no control over injection rate and some degree of sub-optimal injection timing. Unfortunately, ignition delay is strongly affected by timing, so when the engine is mistimed (i.e., too early), ignition delay increases and noise is even worse. With the relatively crude mechanical/hydraulic FIE of the past, engines were always mistimed at some part of the speed/power range, such as idle, early acceleration (before full load), etc., where noise usually was very high.

In addition to the combustion noise, diesels also generate high mechanical noises. The higher cylinder pressures in the diesel cylinder require stronger (and heavier) mechanical components, such as pistons, cranks, connecting rods, etc. The heavier reciprocating components generate higher mechanical loads, especially at high speed, which translate into higher noise and vibration. In addition, some of the FIE used in diesel engines themselves are strong noise generators because of the high cyclic fuel pressures. In fact, some diesel fuel injection pumps make as much (mechanical) noise as the rest of the engine.

The smoke and odor emissions often associated with the diesel engine also have their root in the different nature of the combustion process. Heterogeneous combustion often results in the generation of soot (carbon particles left over from the partial combustion of hydrocarbon), and other more complex chemical species (pyrolized hydrocarbons, aldehydes, etc.). The resulting diesel smoke (soot) is not only readily visible, which in itself is objectionable, but often contains or is mixed with other chemical species, including potentially harmful ones (carcinogens), and others that release unpleasant odors. To minimize these problems, it will be necessary to achieve essentially perfect (complete) combustion, including during load and speed transients. The key to achieving near complete combustion resides in the ability to retain control of air and fuel mixing even during transients. Where control of air and/or fuel is briefly lost, a short plume of smoke and/or partially burned hydrocarbons is released. The faster response and flexibility of electronically controlled fueling offers much improvement. 
Starting and operating engines in cold weather is often a problem that is considered to be far more severe in the diesel. Self ignition is more difficult when the air is cold, and in addition, the heavier middle distillates used for fuel are difficult to handle at low temperatures. If the temperature is low enough to reach the "cloud point" of the fuel, then paraffin waxes begin to solidify and drop out, clogging filters and lines and often stopping flow of fuel altogether. Operation of vehicles under such conditions is virtually impossible without special heaters for fuel tanks and lines, etc. As a result, diesel engines normally include "starting aids" (heaters, glow-plugs, ether dispensers, etc.) to make them easier to start in cold weather, and for extended operation in cold climates, fuel system heaters are often added as options. If diesel powered vehicles are to operate in harsh climates at parity with gasoline powered ones, then they must include such options. The improved flexibility of electronic FIE controls have resulted in superior low temperature starting capabilities, and the increased popularity of direct injection (DI) engines also has been beneficial (DI diesel engines start better than IDI ones), but the delays and/or complexities associated with the use of starting aids remain somewhat vexing. The problems associated with the separation of wax in the fuel at very low temperatures, however, are more fundamental and very difficult to resolve other than by developing special low wax winter fuels and/or heating the fuel tanks and lines.

In spite of the many challenges outlined, there is good reason for optimism. Progress made with modern FIE in the last several years, and the use of electronic control have opened additional treatments to reduce noise and vibration. Electronics allows far more comprehensive control of injection events than ever thought possible before. A few modern fuel injection systems include some degree of injection rate control. Two-spring injectors, for instance, limit injection rate during the ignition delay period, which reduces noise substantially. Turbocharging, now almost universally used, also tends to reduce noise by shortening the ignition delay. Engine manufacturers have learned how to control the transmission of noise from the inner walls of the cylinder to the external surface by clever structural design, and thus managed to reduce airborne noise. These approaches give hope to the task of making a modern diesel engine reasonably competitive in the NVH area with the gasoline engine. More sophisticated control of fuel (and air) also results in reduced smoke and odor emissions, and even better low temperature starting. Therefore, although quite unrelated phenomena, NVH, cold starting and smoke/odor are expected to achieve significant improvement from related hardware development, i.e., more sophisticated electronic controls.

\section{b. Technical Targets}

Possible noise reduction targets based on actual improvements recently achieved with the techniques described above by a truck manufacturer (Mercedes-Benz) could be of the order of: 
- engine near field noise test -- $3 \mathrm{~dB}(\mathrm{~A})$ less than baseline diesel engine, - or $6 \mathrm{~dB}(\mathrm{~A})$ less with noise shields

- vehicle drive-by noise test -- $6 \mathrm{~dB}(\mathrm{~A})$ less than baseline diesel engine without heavy encapsulation

Noise reduction efforts should focus on idle and acceleration, the two most objectionable noise modes for diesel engines. However, specific noise and vibration targets should be set up by industry based on the actual needs to achieve competitiveness with gasoline engines.

The targets for cold start performance should be based on achieving at least perceived parity with the gasoline engine, preferably with fully automatic starting aids that do not add appreciable delay to the cranking process. Similarly, the targets for soot and odor emissions should be based on total or nearly total elimination, so that the current perception of diesels as being smoky and smelly essentially disappears.

\section{c. Barriers}

The key to the solution of most of these problems lies in developing a fuel-injection system and an air-induction system that allow accurate control of injection events and air to fuel ratio throughout the operating range, including transients. Therefore, the main barriers are in the form of development of sensors and components for these systems that are effective and low cost. Control of vibrations will require development of lightweight reciprocating components, which will be a difficult challenge given the higher cylinder pressures expected. Effective noise reduction will also require careful structural design of the engine main components (block and head, primarily), as well as selection of a favorable basic engine architecture. This will involve several compromises with other competing goals, that will further increase already difficult design challenges.

\section{d. Technical Approach}

In summary, the technical approach taken to reduce the NVH of the advanced light truck diesel engine should include the following steps:

- $\quad$ selection of a FIE system that is inherently low in mechanical noise

- selection of a FIE system that provides adequate control of timing events throughout the entire operating speed and load ranges selection of a FIE system that provides control over injection rate, at least during the time delay period, and preferably over the entire operating range

- use lightweight materials for and/or careful design of reciprocating engine components in order to minimize mechanically induced loads and thus noise 
- use advanced structural design of the engine block/head, oil pan, etc., in order to minimize the transmission of noise to the external surfaces

- use basic engine architecture that results in inherently balanced engine (six-in line, 90 deg. $V-8,60$ deg. $V-6$, etc.), and use as many cylinders as possible (V-8 is better than 4 in-line, etc.)

Reduction of smoke and odor will require some of the same treatment above, plus:

- improved control of air/fuel ratio throughout speed/load transient

- fast reacting intake air pressure charger to minimize acceleration response delays

- fuel injection nozzles with minimum dead volume (near zero) to reduce uncontrolled fuel evaporation after end of injection

\section{Fuel Flexibility}

The goal is to determine the feasibility of and, if possible, develop the technologies for liquid flexible-fuel operation on the new advanced diesels being developed under OHVT's Class 1 \& 2 diesel program.

To increase energy security, the OHVT plans to develop the technology required to produce an engine appropriate for Class $1 \& 2$ trucks that has the capability to run on diesel fuel or a liquid alternative fuel. Examples of alternative fuels that may be considered include ethanol, methanol, biodiesel, DME, and DEE. Gaseous alternative fuel engines derived from diesel engines will not be considered for Class $1 \& 2$ diesel trucks because of cost, and because this market is already covered with spark-ignition-based engine designs. The OHVT will focus on researching and developing the technologies by the year 2004 that will be required for the flexible-fuel engine.

\section{a. Status of Technology}

Although several bi-fuel compressed natural gas/gasoline light trucks are being offered by manufacturers, there are no Class 1 or 2 trucks currently available that operate on liquid alternative fuels (either dedicated or flexible-fuel). Most alcohol flexible-fuel engine designs to date have been done on gasoline spark-ignited engines used in passenger cars.

Alternative fuels can displace diesel fuel; however, except for biodiesel, they cannot be directly substituted without substantial engine modifications. With current technology, the optimum efficiency and emissions can only be achieved with engines that are optimized for each fuel. Much of the technology developed for heavier engines may be applicable to engines for Class $1 \& 2$ trucks an even greater factor in this segment. Details on the status of alternative fuel technology in heavy engines are given in the section on Class $7 \& 8$ liquid fuel-flexible engines. 
b. Technical Targets

The primary targets are fuel flexibility and diesel-like thermal efficiency with liquid alternative fuels. Table 9 summarizes the specific targets for each engine parameter for the fuel-flexible engine.

\section{c. Barriers}

The barriers which must be overcome to achieve the technical targets are also listed in Table 9. The primary barrier is probably a market barrier and not a technical one. At present, there is no market demand for a flexible-fuel Class $1 \& 2$ truck engine. The OHVT believes, however, that the development of one should be pursued as a national security "insurance" policy.

Other barriers have more to do with the vehicle than with the engine. The weight of the vehicle can be a barrier due to the extra components required on the engine as well as additional fuel tanks. Any increase in weight reduces load carrying capacity and fuel efficiency. If extra fuel tanks are required, the space availability on the vehicle for the extra tanks can also be a barrier. Insufficient fueling infrastructure is also a barrier to alternative fuel use.

Table 9. Summary of Technical Targets and Barriers for Class 1 \& 2 Liquid Fuel-Flexible Engine

\begin{tabular}{||l|l|l|l||}
\hline $\begin{array}{c}\text { Engine } \\
\text { Parameter }\end{array}$ & \multicolumn{1}{|c|}{ Current Practice } & \multicolumn{1}{|c|}{ Target } & \multicolumn{1}{|c|}{ Barrier } \\
\hline Cost & $\begin{array}{l}\text { No fuel-flexible engine } \\
\text { available now }\end{array}$ & $\begin{array}{l}\text { Depends upon fuel } \\
\text { combination }\end{array}$ & $\begin{array}{l}\text { Costs of extra electronics, upgraded materials } \\
\text { (including fuel tanks, lines, etc.), reliable fuel } \\
\text { sensors. Acceptance of any cost penalty. }\end{array}$ \\
\hline Efficiency & $\begin{array}{l}\text { Maximum efficiency of 39 } \\
\text { percent (for dedicated } \\
\text { methanol engine) }\end{array}$ & 42 percent by 2006 & $\begin{array}{l}\text { Same barriers as for a high efficiency diesel engine, } \\
\text { plus optimum combustion chamber, compression } \\
\text { ratio, injection rate, spray hole size and number, etc. } \\
\text { for different fuels. }\end{array}$ \\
\hline Emissions & No fuel-flexible engine now & $\begin{array}{l}2006 \text { emissions } \\
\text { standards }\end{array}$ & $\begin{array}{l}\text { Difficulty in optimizing control strategies for } \\
\text { multiple fuels. Fixed combustion chamber tends to } \\
\text { compromise emissions due to fuel property } \\
\text { differences. }\end{array}$ \\
\hline Reliability & No fuel-flexible engine now & $\begin{array}{l}\text { Essentially same as } \\
\text { diesel }\end{array}$ & $\begin{array}{l}\text { Additional components and complexity required for } \\
\text { multi-fuel capability tends to reduce reliability. }\end{array}$ \\
\hline
\end{tabular}




\section{d. Technical Approach}

There are no liquid fuel-flexible diesel cycle engines appropriate for Class $1 \& 2$ trucks available now. This program, in partnership with industry, will support research to develop the enabling technologies. The program will address the barriers to developing a prototype liquid fuel-flexible truck. Specific elements of the technical approach to overcoming the barriers outlined in Table 9 are listed below.

- Support research and development targeted at creating a high efficiency engine capable of burning two different fuels. Work may include variable valve timing, EGR, skip firing, Miller cycle, ${ }^{(19)}$ lowering the lean limit, ignition enhancement techniques and advanced sensor and control systems or other approaches shown worthy of pursuit.

- Reduce engine-out emission with techniques such as lowering combustion temperature, EGR, and advanced sensor and control systems. Develop lean-burn NOx catalytic converter for exhaust after treatment.

- Develop fuel tanks compatible with both diesel fuel and the alternative fuel.

- Support R\&D to increase the reliability and durability of key components to the flexible fuel system.

- Evaluate low cost, durable materials for flexible-fuel systems which are compatible with both diesel fuel and the alternative fuel, and develop new materials if necessary.

- Investigate low cost additives to increase the lubricity of alternative fuels.

- Make low cost a priority on all development projects. Identify technology that overcomes the other barriers at the lowest cost. 


\section{Program Summary}

The implementation of this Technology Roadmap is described in the Multiyear Program Plan of the Office of Heavy Vehicle Technologies and Heavy Vehicle Industry Partners. ${ }^{(17)}$ A brief summary only is provided here, and the reader should consult the full program plan for complete information.

\section{Program Goals}

- Develop by 2002 the diesel engine enabling technologies to support large-scale industry dieselization of Class 1-2 trucks, achieving a 35 percent fuel efficiency" improvement over equivalent gasoline-fueled trucks,

- Develop by 2004 the enabling technology for a Class 7-8 truck with a fuel efficiency of $10 \mathrm{mpg}$ (at $65 \mathrm{mph}$ ) which will meet prevailing emission standards, using either diesel or a liquid alternative fuel,

- Develop by 2006 diesel engines with fuel flexibility and a thermal efficiency of 55 percent with liquid alternative fuels, and a thermal efficiency of 55 percent with dedicated gaseous fuel.

\section{Program Approach}

(1) A partnership with the domestic transportation industry, energy supply industry, other federal agencies, and research and development organizations to develop high-efficiency engine technologies and alternative fuel utilization technologies for trucks and promote their acceptance

(2) Continuing development of key enabling technologies.

- Combustion

- Exhaust Aftertreatment

- Materials

- Fuels Formulation

- Natural Gas Storage

- Environmental Effects

Three of these enabling technologies, combustion, exhaust afterteatment, and fuels, will be coordinated through a diesel cross-cut team that has linked diesel R\&D in the OHVT and Partnership for a New Generation of Vehicles (PNGV).

Schedule and Milestones

The OHVT program key activities and milestones are shown in Figure 9.

${ }^{* *} \mathrm{~A} 50$ percent increase in miles per gallon due to diesel fuel higher energy content per gallon. 
Figure 9. Key Activities and Schedule of OHVT.

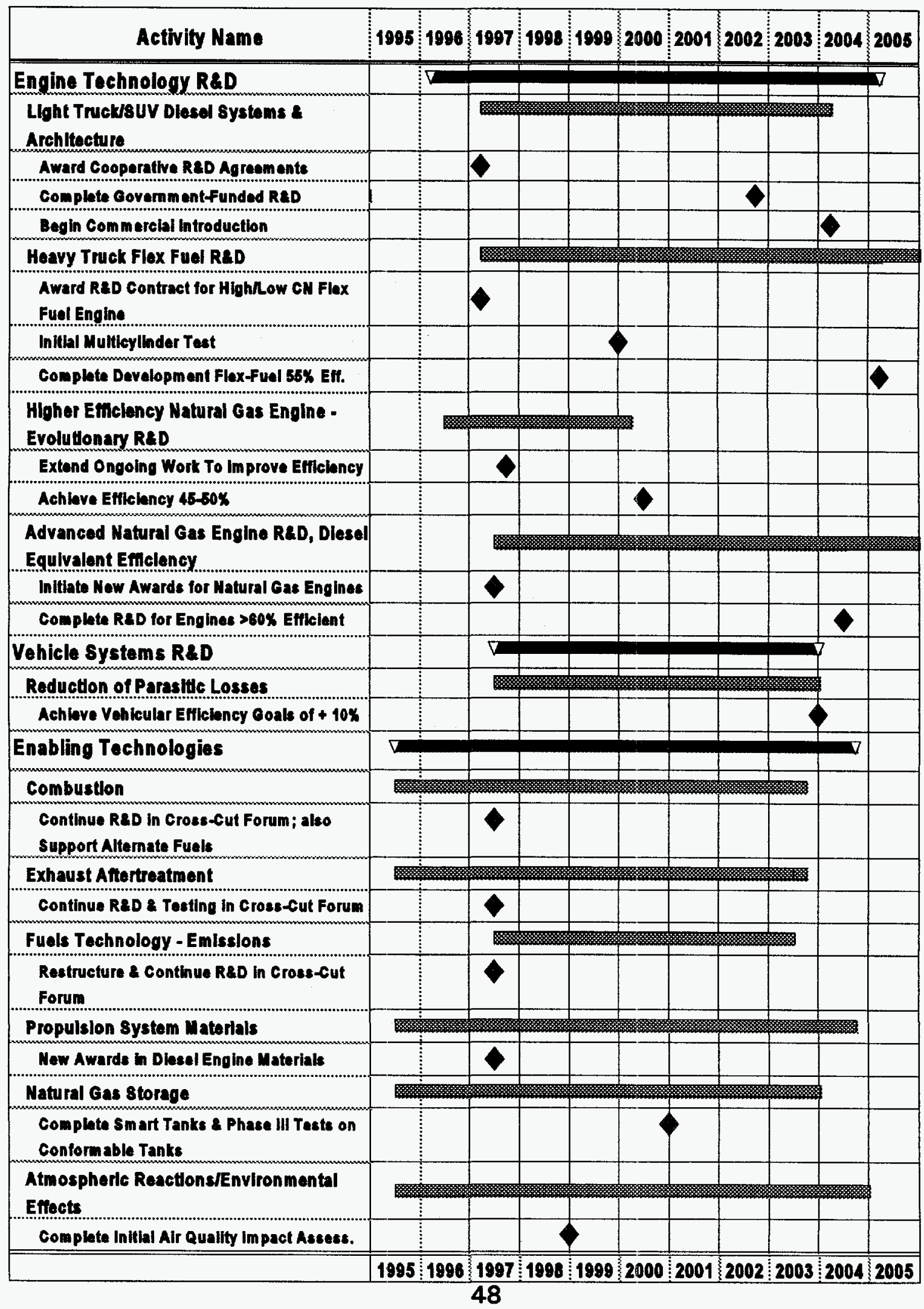




\section{APPENDIX A \\ OHVT Workshops and Meetings \\ Soliciting Customer Input}

1. DOE/SAE Workshop on Energy Efficient Heavy Vehicle Technologies for Reducing Fuel Costs: Leveraging DOE's R\&D Capabilities

Romulus, Michigan, April 17 - 18, 1996

2. DOE/Office of Heavy Vehicle Technologies Customer Focus Workshop

Golden, Colorado, May 14 - 15, 1996

3. SAE Truck and Bus Council Meeting

Miami, Florida, June 24 - 25, 1996

4. DOE/OHVT Workshop on Applications of Carbon Products for Efficient Operation of Heavy Trucks, Buses, and Other Commercial Vehicles Chicago, Illinois, September 4 - 5, 1996

5. 1996 SAE International Truck and Bus Meeting and Exposition Detroit, Michigan, October 14 - 16, 1996

6. DOE Automotive Technology Development Customers' Coordination Meeting

Dearborn, Michigan, October 28 - November 1, 1996

7. Workshop on Alternative Fuels for Heavy Vehicles Chicago, Illinois, November 1996

8. Workshop on Improving Heavy Vehicle Aerodynamics January 1997

9. Diesel Engine Emissions Reduction Workshop

LaJolla, California, July 1997 



\section{APPENDIX B}

\section{List of Acronyms}

$\begin{array}{ll}\text { ANL } & \text { Argonne National Laboratory } \\ \text { C }_{d} & \text { Drag Coefficient } \\ \text { DDC } & \text { Detroit Diesel Corporation } \\ \text { DEE } & \text { Diethyl Ether } \\ \text { DI } & \text { Direct Injection } \\ \text { DING } & \text { Direct Injection Natural Gas } \\ \text { DME } & \text { Dimethyl Ether } \\ \text { DOE } & \text { Department of Energy } \\ \text { EGR } & \text { Exhaust Gas Recirculation } \\ \text { EPA } & \text { Environmental Protection Agency } \\ \text { FIE } & \text { Fuel Injection Equipment } \\ \text { FTP } & \text { Federal Test Procedures } \\ \text { GDP } & \text { Gross Domestic Product } \\ \text { GM } & \text { General Motors } \\ \text { GVWR } & \text { Gross Vehicle Weight Rating } \\ \text { IDI } & \text { Indirect Injection } \\ \text { LDT } & \text { Light Duty Truck } \\ \text { NMHC } & \text { Non-Methane Hydrocarbons } \\ \text { NREL } & \text { National Renewable Energy Laboratory } \\ \text { NVH } & \text { Noise, Vibration, and Harshness } \\ \text { OHVT } & \text { Office of Heavy Vehicle Technologies } \\ \text { ORNL } & \text { Oak Ridge National Laboratory } \\ \text { OTT } & \text { Office of Transportation Technologies } \\ \text { PING } & \text { Pilot Ignition Natural Gas } \\ \text { R\&D } & \text { Research \& Development } \\ \text { SI } & \text { Spark Ignition } \\ \text { SING } & \text { Spark Ignited Natural Gas } \\ \text { SNL } & \text { Sandia National Laboratory } \\ \text { SUV } & \text { Sport Utility Vehicle } \\ \text { ULEV } & \text { Ultra Low Emission Vehicle } \\ & \end{array}$




\section{APPENDIX C \\ References}

1. Office of Transportation Technologies Strategic Plan, August 8, 1996, Pg. 1.

2. Stacy C. Davis, Transportation Energy Databook, Edition 17, ORNL-6919, Center for Transportation Analysis, Oak Ridge National Laboratory, August 1997.

3. John B. Heywood, Internal Combustion Engine Fundamentals, McGraw-Hill Publishing Company, 1988, pg. 883.

4. L. R. C. Lilly, Diesel Engine Reference Book, Butterworths Publishing, 1985, pgs. 1/7, 1/9.

5. Charles F. Taylor, The Internal Combustion Engine in Theory and Practice Volume 1: thermodynamics, Fluid Flow, Performance, M.I.T. Press, 1985, p. 135.

6. R. R. Covey, Preliminary Heavy-Duty Truck Energy Balance, Aerospace Corporation, August 1982.

7. R. L. Graves, D. L. Greene, and E. W. Gregory II, Application of the Adiabatic Diesel to Heavy Trucks--A Technology Assessment, ORNL/TM-9554, March 1986.

8. H. M. Sachs et al., Heavy Truck Fuel Economy: A Review of the Technologies and the Potential for Improvement, American Council for an Energy-Efficient Economy, Washington, D.C., January 1992.

9. G. F. Roberts and D. L. Greene, Trends in Heavy Truck Energy Use and Efficiency, ORNL/TM8842, Oak Ridge National Laboratory, October 1983.

10. R. L. Wiley and . L. Levine, Aerodynamic Design Effects on Passenger Car and Truck Fuel Economy, Aerospace Corporation, ATR-83 (3869)-IND, December 1982.

11. B. Randall, An Integrated Approach to Truck Fuel Saving, Automotive Engineer, January-March 1991.

12. Federal Register, Vol. 58, 15781, March 24, 1993.

13. Federal Register, Vol. 61, 33421, June 27, 1996 (Proposal, not final rule).

14. R. H Hammerle, et al., "Emissions from Current Diesel Vehicles," Society of Automotive Engineers Paper No. 942043, 1994.

15. K. J. Springer, "Diesel Lube Oils - 4th Dimension of Diesel Particulate Control," American Society of Mechanical Engineers, ICE-Vol. 4, 45, 1988.

16. R. H. Miller, Supercharging and Internal Cooling Cycle for High Output, Trans. ASME 69, 1947

17. Multiyear Program Plan of the Office of Heavy Vehicle Technologies and Heavy Vehicle Industry Partners, Draft, October 1997. 